History and society

Тарих һәм жәмгыять

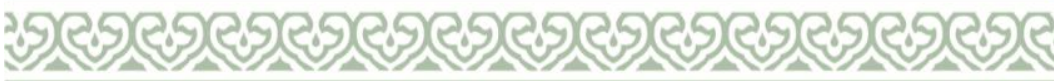

История и общество

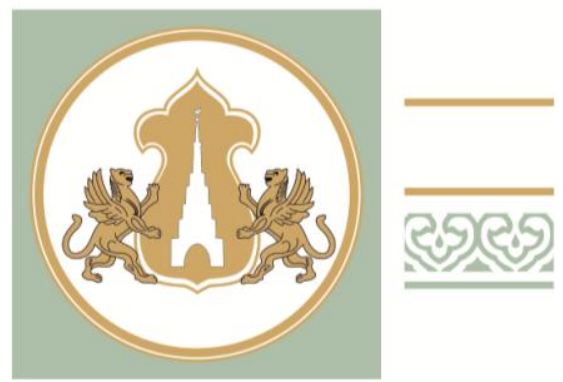

\title{
THE ALLIANCE OF THE CRIMEAN KHANATE WITH RZECZPOSPOLITA, 1654-1657: MILITARY ASPECTS
}

\author{
Yaroslav Valentynovych Pylypchuk, \\ National Pedagogical University named after M. P. Dragomanov, \\ Room 24, 6 Osvity Str., Kyiv, 03037, Ukraine, \\ bachman@meta.ua.
}

\begin{abstract}
This article addresses the issue of the military and diplomatic aspects of the Crimean Khanate alliance with the Polish-Lithuanian Commonwealth in 1654-1677. In 1654, the system of international relations was reformed in Eastern Europe. The placement of the Cossack Hetmanate under the protectorate of the Russian state led to establishing close cooperation between the House of Gheray and the House of Vasa. The Crimean Tatars defected the side of the Poles, which forced the Cossacks to adopt a defensive attitude. The Russian-Ukrainian army managed to avert defeat near Akhmatov in 1655 due to B. Khmelnytsky's diplomatic talent, I. Bohun's successful offense and the reluctance of Mehmed Giray IV and the Crimean mirzas to allow one of the sides to achieve the final victory. The battle of Oserna in 1655 caused heavy casualties among the Ukrainians. The help of the Crimean Tatars to the Poles in the battles of Prostki and Chornyi Ostriv brought about the defeat of the Brandenburgers and the Transylvanians, respectively. Using Polish contacts, the Crimeans sent embassies to the Austrian Empire, Denmark and Sweden. The attempt to convince Denmark and Sweden to join the anti-Russian coalition was unsuccessful. The Ottomans sanctioned the campaign of the Crimeans against the Transylvanians in 1657.
\end{abstract}

Key words: Rzeczpospolita, Cossack Hetmanate, Crimean Tatars, Crimean Khanate, international affairs, Girays.

One of the most significant events in the history of Eastern Europe was signing a treaty between the Russians and the Ukrainians in 1654 known as the March Articles. The Cossack Hetmanate was placed under the protectorate of the Russian state (Muscovia) and received extensive autonomy. This event triggered the reformation of coalitions in Eastern Europe. The present study focuses on the military alliance of the Polish-Lithuanian Commonwealth with the Crimean Khanate, the clashes between the Tatars and the Ukrainians, the Transylvanians and the Swedes. This aspect is primarily

discussed in the studies of such Polish researchers as D. Kolodzejczyk [Kolodzejczyk] and L. Podhorodecki, [Podhorodecki]. As regards Russian researchers, this issue is raised by G. Sanin [Sanin, 1987] and A. Malov [Malov]; among Ukrainian scholars the problem is studied by Ia. Fedoruk [Fedoruk, 2010], [Fedoruk, 2011], [Fedoruk, 2012], [Fedoruk, 2012], V. Smolii, V. Stepankov [Smolii, Stepankov], T. Chukhlib [Chukhlib, 2010], [Chukhlib, 2017]. The study aims at examining the military and diplomatic as- 
pects of the Crimean Khanate alliance with the Polish-Lithuanian Commonwealth in 1654-1657.

The issue of the Polish-Crimean alliance is mostly discussed in diplomatic documents. In December 1653, negotiations were conducted between the Crimeans of Sefer Gazi Aga and the Poles. On December 15, the Treaty of Zhvanets was negotiated, according to which Ian Casimir confirmed the conditions of the Treaty of Zboriv, paid the khan 200 thousand thalers and promised to give 30,000 thalers as upominki (a gift) annually. Despite the fact that the Treaty of Zhvanets revised the conditions of the Ukrainian-Polish Treaty of Bila Tserkva, since those were severe for the Cossacks, B. Khmelnytsky decided to change the foreign policy and joined the alliance with the Russians. This led to a change in the system of political relations [Pernal, pp. 118-120], [Litopis gadiatskogo polkovnika Grigoriia Grabianki], [Grushevskii], [Cofonovich], [Podhorodecki, pp. 182-186].

On July 18, 1654, Ian Casimir made peace with the Crimean Khanate. Crimean envoy Suleiman Aga arrived at a meeting of the Saeima in Warsaw. The king of the Commonwealth and the Crimean khan continued to be referred to with pretentious titles. They mentioned the long tradition of friendship between the states, as well as the longstanding commitment of the Polish-Lithuanian Commonwealth to pay upominki. It was said that the tsar of Moscow invaded the kingdom together with the Cossacks. The lands of the Grand Duchy of Lithuania were the target of the invasion. The Crimean khan and his successors pledged to provide assistance to the Poles, that is, not to sign a separate treaty with the Russians and the Zaporozhian Cossacks. It was indicated that when the Cossacks and the population of Ukraine returned under the rule of the Commonwealth, the king would not allow raids from the other side, which would cause the war. It was mentioned that the Poles agreed to be allies with the vassals of the Ottoman Empire - the Transylvanian prince George II Rakoczi, the masters of Moldova and Wallachia. In the document dated July 20, 1654, Ian Casimir swore an oath on the Holly Gospel and promised to fight against the Russians, maintaining friendship with Islam Giray and the hordes subordinate to him. The senators' oath to be friends and form an alliance with Islam Giray against the Russians is of the same date. Having signed a treaty with the Russian state, Bohdan Khmelnytsky wanted to maintain good relations with the Crimean Khanate. The Ukrainian envoys to Istanbul asked the sultan to allow the khan to maintain peaceful relations with the Zaporozhian Cossacks. Khmelnytsky wrote a letter to Islam Giray, in which promises of everlasting friendship were made. The Crimean vizier Sefer Gazi Aga blamed the hetman for signing the treaty with the Russians. In May, 1654 the Crimean envoy stayed in Chigirin, and returned to Crimea in early June. In the summer Tatar troops began to prepare for the invasion of the Cossack Hetmanate. In August, Islam Giray died, which somewhat postponed the invasion. The new khan sent his emissary Kamambet Mirza to the hetman, offering an alliance, but demanding to leave the Russians. In response to this, the hetman sent an embassy headed by Mikhail Bogachenko to Crimea. In October, Mehmed Giray began to threaten the hetman. In the same year negotiations were held with Crimean envoy Toktamysh Aga. In January, 1655 a new round of negotiations was held near Akhmatov during the Crimeans' march on Ukraine. At the same time, the hetman received an offer from Karach Bey and some of the sultans to form an alliance against the Poles, but on condition that they would break the treaty with the Russians. On November 12, 1655, the Ukrainians and the Crimeans signed a truce near Oserna. Being in a difficult position, the hetman was forced to sign an extremely disadvantageous treaty. However, Bohdan Khmelnytsky did not have any serious intentions to implement its provisions. In January, 1656, he negotiated that the Ukrainians and the Crimeans should release the captured Tatars and Ukrainians from captivity. In April, 1656, the Ukrainians informed Perish Aga, the Perekop bey, about their embassy in Crimea. In his letter to Ian Casimir Khan Mehmed Giray asked not to sign a peace agreement with the Russians and advised him to sign an agreement with the Swedes instead. After the Russians and the Poles signed the Truce of Vilna, the khan asked Ian Casimir to renounce the alliance with Moscow [Kolodzejczyk, pp. 964973], [Pernal, pp 129-184], [Chukhlib, 2010, pp. 196-199], [Chukhlib, 2017, pp. 43-46].

In this regard, it is necessary to provide an overview of the 1654-1655 campaign in the Ukrainian lands. At the end of 1654, the Crimeans joined the war on the side of the Poles. According to Dvoretski Chronicle, Khmelnytsky defeated many Poles, and the Tatars suffered losses near Dryzhipol in 1655 [Mitsik, 1984]. F. Sofonovych reported that in the fall of 1654, the Poles came to Bratslav and the Tatars joined them there. It was noted that not the Tatars, but the Poles defeated 
Tomilenko, and the other colonels were forced to retreat to Uman. By 1655, it was reported that the Poles and Tatars had besieged Uman and assaulted it for over three days. Khmelnytsky and Sheremetev came to rescue the city, but were encircled on Dryzhipol, between Akhmatov and Stavyschi. It was mentioned that the Cossacks and the Russians fought back against the Poles and the Tatars courageously. It was stated that after that Khmelnytsky and Buturlin moved to Lviv and took war indemnity from this city. However, when the Cossacks returned, the Tatars encircled them near Oserna. Many Cossacks were captured by the Tatars, but the Russians and Ukrainians, in general, were able to repel the assault of the Tatars. Many Russians died not in the battle, but during the retreat in the winter [Cofonovich].

According to Chernigov Chronicle, there were many Tatars near Ukrainian cities. It was reported that the khan came to Smila, Volkhovets and Zvenyhorodka. It was noted that the khan got angry with Khmelnytsky because the latter had acquired Russian citizenship, and with many Cossacks, who came from the Lviv region which they had besieged together with the Russians; he nearly caught Khmelnytsky near Oserna. However, the Cossack hetman used diplomatic skills and managed to negotiate with the Crimean khan [Chernigovskaia letopis].

It is mentioned in Lyzogub Chronicle that in 1654 Ian Casimir sent 100,000 zlotys to Islam Giray III, but only the next khan accepted this sum. Having received this money, he came to Ukraine and devastated many lands. In 1655 it was reported that the Poles and the Tatars besieged I. Bohun near Uman, and then encircled Khmelnytsky between Stavyshchi and Akhmatov, but the Cossacks repulsed their attacks. After the siege of Lviv the Cossacks went back in separate detached units, and the Tatars destroyed them. They pressed Khmelnytsky near Oserna, but he managed to fight back and then made an agreement with the khan, who gave several members of the Girays as hostages. The Cossack hetman met with the Crimean khan, who threatened him and reproached him for accepting the protection of the Russian tsar but not of the Turkish sultan. The khan himself wanted to reclaim Astrakhan from the Russians. Khmelnytsky, however, emphasized that the Tatars had considerably benefited from a joint war with the Cossacks against the Poles and took the yasyr. $\mathrm{He}$ also reproached Islam Giray III for fleeing from the battlefield at Berestechka [Lizogubivskii litopis].
The Samovydets Chronicle indicated that in the winter of 1654-1655 the Polish king sent envoys to meet the khan in Crimea, and the latter arrived with great forces. It was reported that the Ukrainians were surrounded at Dryzhipol, between Slobodyshche and Uman, and there were many Poles and many Tatars in the battle. The chronicler did not mention the battle of Oserna [Litopis Samovidtsia].

S. Velychko stated that the khan sent his army against the Poles, without waiting for the king to fulfill the Treaty of Zhvanets conditions. To take the yasyr, the Crimeans spread across Volhynia, Polesia, and also reached the Polish lands near Zamosc and Lublin. It was reported that the Sapieha family, sent against the Tatars, defeated a number of Chambuls. Then, passing through the lands from Ukraine back to Crimea, the Crimeans robbed them. It was noted that 15 thousand Tatars, who acted in the Grand Duchy of Lithuania, were to return through the Kiev region. The Cossacks met and killed them near Belgorodka and Mezhyhirya. The people, taken in the yasyr, were released. A thousand five hundred Tatars and eleven mirzas were captured and other plunder was distributed among the Cossacks. It was reported that after envoy Jaskolski had arrived from Crimea, Tatar envoy Suleiman Aga appeared at the Polish court. He demanded a tribute of 600,000 and an oath that the Poles would not fight against the Crimean Khanate. The king promised to fulfill these conditions, and the khan, in turn, promised to send a considerable number of troops against the Cossacks. The Poles promised that the Transylvanian prince and the rulers of Wallachia and Moldavia would come out against the Cossacks. Some time after the death of Islam Giray a new khan rose to power in Crimea. He confirmed the alliance with the Poles with the help of the kalga, the second most important person after the khan. Khmelnytsky tried to split this union diplomatically, sending a messenger to the khan, but after the council with the mirzas he was determined to maintain the peacekeeping policy with the Poles. In 1655, it was reported that the khan had issued an ultimatum to Khmelnytsky, demanding that he should limit the Cossacks to 10 thousand in registry, allow the Polish gentry to return to their lands, refuse to ally with the Russians and recognize only the king of Rzeczpospolita as their sovereign. The hetman refused to agree to this, and the Tatars met the Poles near Uman. The Tatars were headed by the son of the deceased khan. His troops took the yasyr on the territory of the Dnieper, and the total 
number of troops was 40 thousand. B. Khmelnytsky with 25 thousand warriors moved to Akhmatov, and four miles from there they were encircled by the Poles and the Tatars in the open field. The good outcome of the battle for the Cossacks predetermined the attack of I. Bohun to the rear of the Poles. At the same time, Khmelnytsky also came out against the Poles and the Tatars, so that the Poles and the Tatars were forced to retreat. The Russian army helped the Ukrainians. At the same time, the Poles suffered most of the losses in the Battle of Dryzhipol, while the Tatars retreated with the yasyr. First, one part of them left the battlefield, and then the others followed. Meanwhile, the Polish hetman faulted the mirzas for the defeat in the battle, they became angry and left the battlefield. A part of the Tatars, sent by the khan to take the yasyr in Polesye, did not return yet. Khmelnytsky took advantage of this, sending 10 thousand Cossacks headed by Bohun against them. He defeated individual Tatar detachments, which were returning to the camp near Uman, near Chudnov, Kotelnyi, Kodno and Kormin. 8000 Tatars were killed and 2050 people were taken prisoner. Khmelnytsky sent 500 of the captured Tatars as a gift to the Russian Tsar. Only those Tatars that had been in Polonne were able to return home intact and with the yasyr. Those Tatars that were not presented to the Russians bought themselves out from captivity [Velichko].

G. Grabianka noted that in 1653 the Tatars took many prisoners, returning back through the Ukrainian lands. Then the Poles joined the alliance with the Crimeans, and the king promised the khan to help recapture Astrakhan. In return, the khan promised Poland to conquer Ukraine. Under such conditions the Ukrainians became citizens of Russia. The Cossack chronicler retold the rumor that the khan was poisoned by a Ukrainian slave, who served the khan wine. It was reported that the new khan defeated Tomilenko, the appointed hetman, and besieged I. Bohun near Uman in the winter of 1654-1655. B. Khmelnytsky went to his resque, but he was surrounded by the Poles and the Tatars near Stavyshchi and Akhmatov. It was reported that the battle was mainly between the Cossacks and the Poles. On the second day the Poles and the Tatars attacked the Cossacks again, but the Cossacks bribed the Tatars, and the Poles kept fighting the Cossacks until Bohun came from Uman. The Tatars took the yasyr and asked the Poles to go to the Dnieper, but they could not do it as they had suffered losses. When the Cossacks were returning from a campaign in Lviv, the Tatars encircled them near Oserna, but could not defeat them, so they conducted negotiations. The khan reproached the hetman for having forgotten the good that the Tatars did to him when he fought against the Poles, who even the Austrian kaiser was afraid of. The Cossack hetman pointed out that the khan had sent only Tugay Bey at the beginning of the uprising. He noted that the Cossacks had been victorious near Korsun and Pylyavtsy, and that there had been only 4-thousand army of Karach-Bey near Pylyavtsy. The hetman accused the khan, claiming that the will of the Crimean khan did not allow him to defeat the Poles near Zboriv and Zhvanets; that the khan's ships could sail in the Black Sea and along the rivers only thanks to the Cossack's free will; that Islam Kermen was safe because the Crimeans joined the Poles, since it was enough for them to promise that they would recapture Kazan and Astrakhan with the help of the king. The khan replied that Khmelnytsky was afraid to say such words to Islam Giray. However, it is unlikely that such speeches were made by the hetman and the khan themselves, otherwise they would not have found a compromise. These words were attributed to them by the Cossack chronicler, who did not even try to hide his anti-Tatar position, several decades later [Litopis gadiatskogo...]. The Ukrainian chronicle "On the Beginning of Peace, especially on Poland and Little Russia" indicates that the Tatars almost defeated Khmelnytsky in the attack near Oserna in 1655 [Mitsik, 2015, p. 238].

The Poles present a somewhat different description of the events. On January 29, $1655 \mathrm{~J}$. Jerlicz reported that the Tatars, led by the kalga and the Poles, met with the Cossack and Russian army of more than 100 thousand people between Piatyhory and Akhmatov. The forces of the Tatars were estimated at 40 thousand people. The Poles were winning the battle, and the Russians wanted to defect to the Poles. I. Vyhovsky began to retreat to Akhmatov, and his detachment was captured by the detachment of Lanckoronski and a part of the Tatars. Seeing the unfavorable course of the battle, Khmelnytsky bribed some mirzas, and they left the battlefield. It was reported that the Russians and the Cossacks then came to Lviv, while the Poles called on the Tatars for help in order to hold off the attack. The Crimeans passed near Galich, Peremyshl, Jaroslaw, and the local population suffered from them. It was noted that Khmelnytsky was surrounded by the troops of the khan in Oserna near Zborov and Ternopil. A number of Russian boyars died in the battle. Then the khan moved to the Dniester and Kamyenyets. There used to be 40 thousand people, 
and after the Crimeans had left the land, there were about 8 thousand people left [Erlicz, pp. 167-168, 173-174, 176-178].

According to "Short Story of the Khmelnytsky Upriot", in 1655, the Poles and the Tatars set off against the Cossacks and the Tatars went to Zaporizhia for the yasyr. It was reported that the Poles would have defeated Khmelnytsky near Akhmatov but for I. Bohun, who had attacked in their rear. Although the Crimeans surrounded the Cossacks, they thought more about gifts and plunder than about the success of the joint campaign. When the Tatars took the yasyr, Khmelnytsky was able to leave for Bila Tserkva [Kratkaia istoriia o buntakh Khmelnitskogo...], [Historya o buntach Chmelnickiego].

W. Kochowski noted that in 1654 the khan had liberated two hundred notable Poles, who were in captivity among the Tatars, as a sign of goodwill. The khan sent 30 thousand soldiers to help the Poles, and these forces joined the Poles on October, 28. 20 thousand cavalry and 8 thousand infantrymen of the Poles joined the Crimeans. The Poles took Murafa and Krasne; Czarniecki planned to take over Kiev. The Crimeans united with the Poles at Bratslav. The Crimeans were headed by mirzas Akhmet and Kamambet. Together they took Dembovka, but they could not take Uman, strengthened by I. Bohun. Khmelnytsky and the Russians were going to help the besieged, but the Poles and the Tatars encircled them near Akhmatov. W. Kochowski greatly exaggerated the enemy forces, indicating that there were only 80 thousand of the Russians and 20 thousand of the Kalmyk horsemen. The Poles fired at the camp of the Cossacks and the Russians with cannons. Lanckoronski wanted to take over the RussianUkrainian camp without losing the strength of the cavalry. At night the Tatars retreated from the camp. The Poles asked them why they had retreated, and were told that they were not accustomed to fighting at night and that it was freezing. The Polish infantry suffered no less, and many of them died because of frost. Then, according to the chronicler, it became known that Kamambet was bribed by Khmelnytsky, and then the envoys were sent to bring the kalga gifts. The Poles were forced to retreat, the Crimeans retreated to their possessions and gathered with Russian and Ukrainian people, taken into the yasyr, near Savran. The khan promised Ian Casimir 100-thousand troops. 20 thousand Tatars of Zikh mirza came to help the king against the Swedes [Kochowski, pp. 187-199, 201-202, 212, 223].
In Samuel Twardowski's "Wojna Domowa" it is stated that the khan died and a new khan arrived in Crimea. The kalga and the khan's brother consulted with the new ruler and sent the envoys to the king to offer him friendship. The letter was sent with Chelebi. The khan promised to break the alliance with the Cossacks and be an ally against all enemies. On his way back Chelebi met a Ukrainian envoy, who promised great gifts. The Crimean ruler negotiated with both parties. The Crimeans attacked the Cossacks, the Poles invaded the Bratslav land. Melin Giray (Mengli Giray) brought a 40 thousand army. It was noted that the Tatars robbed the Ukrainian villages, and some time later Mehmed Giray appeared with a large horde. Samuel Twardowski noted with regret that such friendship made no sense, for which they paid with the lives of the Christians; they should not have joined an alliance with the Tatars and paid for the union with the yasyr of the Christians. It was also mentioned that, unfortunately, the Treaty of Zboriv and the Greek faith was not adhered to [Mitsik, 2015, pp. 230-234], [Twardowski].

In "The Rhymed Chronicle" Samuel Grondski mentioned that there were 100 thousand of the Russians and the Ukrainians, and a few tens of thousands of the Tatars. The Tatars informed the Polish hetman that a huge army was coming to him. The army was encircled in Akhmatov. It was noted that, shouting "Allah, Allah", the Tatars charged onto the Russians hard, and together with the Poles they almost seized the Russian-Ukrainian camp near Dryzhipol. Khmelnytsky bought the nureddin over, promising him gold and silver provided that he would not attack the Ukrainian camp. The Poles resented the nureddin for his behavior. Then the Tatars began to seize the villages and cities inhabited by the Poles. The Poles were afraid, because they thought that they were attacked by a numerous Tatar horde. To secure the alliance with the Tatars, the Poles provided a free way to Ukraine and did not prevent them from taking the yasyr. The Tatars inflicted a lot of damage on the Russians and the Ukrainians. A lot of people were enslaved. In 1657 Khmelnytsky wanted to bring the khan and his horde to Poland. In 1659, J. Lubomirski together with the Tatars invaded Hungary. Previously, in 1658, the Poles fought in Transylvania and only in 1660 were their troops withdrawn from the country. It was reported in 1658 that the khan had defeated Janos Kemen on the Strypa River near Zarvanytsia. Many Hungarians were captured by the Tatars. The Polish chronicler compared them with the wolves and described their unpretentious nomadic lifestyle. 
It was noted that the Tatars were ready to attack the Poles, the Germans, the Russians, the Ukrainians and the Hungarians. In "The Chronicle of the Polish-Cossack War" S. Grondski indicated that the Tatar khan had come to Ternopil and the Crimeans destroyed many Russians, who were separated from the Ukrainians. Then the khan waited for the Poles to appear in Pokuttya [Mitsik, 2015, pp. 259-263, 268-281, 298-299]. The Moldovan chronicler Miron Costin reported that the Cossacks had abandoned the Tatars and accepted Moscow citizenship. In the winter of 1654-1655, the Tatars together with the Poles inflicted many losses on the Cossack land. They besieged the Ukrainians and the Russians in the same area [Miron Costin], [Mitsik, 2015, pp. 308-309].

S. Rewera Potocki pointed out that the Tatars did appear on time. Ottoman Sultan Mehmed IV wrote that in the winter of 1654-1655, having broken the oath, he fought with the Moldovans and the Hungarians against the Ukrainians. In the given circumstances Khmelnytsky asked for the Turkish protectorate over the Cossack Hetmanate. The Turkish Sultan offered the Ukrainians to improve relations with the ruling khan (Mehmed Giray IV). On November, 2 the conditions of the CrimeanUkrainian reconciliation were announced: the Cossacks were ordered to leave the Russians and recognize Ian Casimir as their legal ruler. Under these conditions, there should be 6 thousand registrants, and they should be mixed with Polish and Hungarian infantrymen, so that the Ukrainians would not take any diplomatic actions without the consent of the king; one more condition was that they should defeat Karl X Gustav. It is obvious that the Ukrainians could not agree to such conditions. On Novembe 27, Mehmed Giray mentioned in the letter to S. Potocki that he had devastated a part of Ukraine, but had to stop at the Salt Town to fight against the Ukrainians and the Russians. The khan promised the Polish hetman to cover the lands from Kamenka to Zboriv with the dead bodies of the Cossacks, who were on their way back from Lviv. He also promised to eliminate the Swedes. Two days later he wrote to Marshal of the Crown J. Lubomirski and reported that the Crimeans were in Pokuttya, waiting for the Poles to join them. M. Jaskolski, the envoy of Rzeczpospolita to Crimea, reported that the khan had come to Ternopil and summoned the mirzas and the beys to the council. Later, some detachments came to Ternopil, Mykulyntsi, Trembowla and Storojiv. When the Ukrainians and the Russians were crossing the river near Oserna, they were attacked by the Nogais from the Crimean army. They immediately killed a few hundred Russians. The Ukrainian and Russian army was besieged in Dibrova. During the battle Ian Casimir sent a letter to the khan, where he suggested bringing Khmelnytsky to reason. When the Tatars began to crush the Ukrainian troops, they were faced with fierce fire from muskets and cannons. Kamambet was injured, and then Subhan Kuli Aga, Az Mirza and Karach Bey began negotiations, reproaching Khmelnytsky for having broken the oath given to Togay Bey. The Ukrainians answered that they had joined the alliance with the Russians because the khan had signed the alliance with the Poles. The Crimeans also said that they had sent envoys many times and demonstrated their friendliness, so that the Ukrainians would leave the Russians. The Cossack envoys said they were ready to live in peace with the Poles and the Crimeans. However, they absolutely refused to fulfill the ultimatum requirement for the extradition of the Russians to the Crimeans, saying that it would be a great sin. After that fights between the Ukrainians and the Crimeans resumed, but the clashes stopped in a while. The khan gathered the council and decided to reconcile with Khmelnytsky and cancel the requirement of releasing the Russians, just to have peace and alliance with the Cossacks. The khan gave Buturlin a horse. The only condition was that they should become the subjects of Ian Casimir [Mitsik, 2015, pp. 14, 25-26, 3032, 34-35].

On April 20, 1656, I. Vyhovsky sent a letter to Perekop Pyrish Aga. He asked the aga to advise the khan to maintain friendship with the Cossacks, proposing to fight together against common enemies. In a document dated February 25, 1657, Kazimir Stakhovski, captured by the Russians, reported that B. Khmelnytsky was ready to become an ally of the Tatars, the Swedes, the Hungarians and the Poles against the Russians. The German leaflet said that the army of George II Rakoczi consisted of the Seimens (Seimen-Tatars), the Cossacks, the Walachs, the Moldovans, the Hungarians, the Zbojniks. After May 8, 1657, the confessat of Hungarian, Swedish and Cossack prisoners indicated that the Swedes had sent envoys to different countries. The royal chamberlain Lelizor arrived in Crimea. It was noted that the troops of Rakoczi comprised 37 thousand people, 7 thousand of whom were the Germans, the Cossacks and the Seimens. In a document dated June 3, 1654, Martyn Pushkar and Yakiv Barabash said that they were standing in the field, protecting the country from the attacks of the Tatars. They asked 
I. Vyhovsky to give a sign to the khan so that the Crimeans would retreat from the lands of the Ukrainians. Ivan Zheliabuzhski wrote to George Rakoczi that Colonel Onton (that was what he called Anton Zhdanovich) was ready to fight against the Turks and the Tatars in KamianetsPodilskyi. He then said that they would not be able to join the Hungarians at Kamianets-Podilskyi, because the Russians were at war with them. Later, the Crimean khan came to the city with the whole army. It was noted that the army of the Ukrainians was scattered, then the Crimeans defeated the troops of George II Rakoczi, and after the victory they took the treasury of the Transylvanian prince and the yasyr to Crimea. They fought in Moldova as well. The Crimeans called the Poles to fight against the Ukrainians. However, they refused to attack the Cossacks. The Tatars resented the Poles, because they did not hand over George Rakoczi. The Polish king paid some money to the Crimeans for their help. In his letter to Pavlo Teteria, dated August 11, 1657, Evstafy Vyhovsky wrote that the Cossacks had terribly devastated the Crimean Khanate. The letter to an unknown person in September 1657 indicated that the inhabitants of Pinsk helped the Cossacks defeat the Tatars. Silistrian Pasha Chaush wrote to Bohdan Khmelnytsky that the Cossacks and the Tatars had a quarrel. The news from Warsaw said that the Crimean envoy arrived in the city in December and offered to fight against the Cossacks, because it was a good time to defeat them [Mitsik, 2015, pp. 53, 71-72, 78, 9596, 102, 104-105, 109-110, 113-116, 123, 131132].

In the letter dated October 26, 1654, Mikhail Bogachenko, the Ukrainian envoy to Crimea, wrote that he was sent to the embassy by a Pereyaslav colonel from Kamenka together with Kamambet Mirza. He arrived in the Kelimbet ulus. At that time the Tatars were restless. Bluhdas Sultan, Sefan Gazi and Sefer Gazi Aga sent Kamambet Mirza to the embassy to intimidate the rebellious sultans with their troops. When they heard about the embassy of the Zaporozhean Cossacks in Dzhan-Kermen, Koraga Sultan and Sefer Gazi made peace with the beys. Nureddin Sultan and Safan Gazi Aga stood at Perekop. Kamambet was afraid of them and walked around Perekop through estuaries. The embassy was supposed to hand over the documents to the khan and the beys, which Bogachenko did. The envoy was sent to Old Crimea. Khorunzhiy Korycki arrived to Nureddin Sultan and Safan Gazi Mirza. There he learned that the Tatars decided to fraternize with the Poles and ruin the whole Ukraine with fire and sword. Kamambet Mirza swore to the Polish envoy that he would help the king and capture Khmelnytsky. The Ukrainians were reproached for forming an alliance with Moscow. The army of Tatars gathered at Perekop and stood there for several weeks. The Kiev scribe reported the information from a Ukrainian slave in Crimea. All summer the Poles and the king sent envoys to Islam Giray and to the beys. The khan sent mirzas to the king. The king himself swore an oath to the Tatars, and so did the senate. The Tatars told the Ukrainian envoys to leave Moscow and said that they had an order from Istanbul to fight together with the Poles. Three days later Karach Bey summoned the Cossack envoys. He gathered together with abyzes, kadis, mirzas, and demanded that the Ukrainians leave Moscow. If that had not been done, Ukraine would have been ruined by the troops of the Turks, the Hungarians, the Walachs and the Poles. At that time Baitemir Aga, the Crimean envoy to Ukraine, came and said that the hetman had asked the Tatars to take the oath, and then he would sever all ties with Moscow. Then Sefer Gazi Aga called on the Ukrainians and demanded that they leave Moscow and return under Polish direction. Karach Bey said that all the Cossacks would die if they did not leave Moscow. He would defeat the Cossacks first, and then Moscow. Then the envoys visited the khan, who said that he wanted to live with the hetman, like the former khan (Islam Giray). The khan sent Kaia Bey to the Nogai mirzas (to Budzhak, to be exact). Kalga Sultan also had to cross over to the right bank of the Dnieper. After the Ukrainian envoys left, the khan released the Polish envoy together with Ali Bey, the son of Togay Bey. Khorunzhiy Jaskolski was left in Crimea. Bekganovski and Beletski were sent to the Turkish embassy. Then the Sultan promised to send 100-thousand troops to Moscow. Safar Kazi Aga Lever, the interpreter of Ivan Vyhovsky, escorted the embassy, headed by Mikhail Bogachenko, from Crimea [Chukhlib, 2017, pp. 203-206].

Lithuanian Major General Ignatus Scipion reported that in 1655 the Crimean khan forced Khmelnytsky to recognize John Casimir as his king. The autobiography of Boguslaw Radziwill stated that Boguslaw was captured by Subkhan Gazi in the battle of Prostki in 1656, but was released by pan Voinovich. In the memoirs of A. Radziwill it was mentioned that in 1655 the Crimean khan brought Khmelnytsky to make him serve the king. Nikolai Emelevsky reported that the 
khan's brother came to Uman with 20-thousand army and, together with the Poles, spent two weeks there, assaulting the fortress. 60 thousand Russians and Ukrainians were surrounded by the Tatars and the Poles near Akhmatov. It was noted that the Tatars, who were long-standing allies with the Cossacks, twice retreated unexpectedly during the assault. The kalga with 60-thousand army came to Transnistria and met with the Crimeans in Bershad. It was noted that the Tatars received a lot of gold and other forms of wealth from both the Poles and the Ukrainians. S. Lanckoronski indicated that the Polish hetman met with the khan in Obodiwka. Among the khan's retinue there were Kamambet and Akh (Ak) Mirza. The letter of the unknown to the unknown, dated February 4, noted that the enemy had sent gifts to Kamambet Mirza, so that the Tatars would get separated from the Poles. The Tatars retreated from the battle. The Russian envoys to Crimea denounced that there was the nureddin, but the kalga was fighting in Ukraine, and the Tatars had brought many prisoners from there. The letter dated February 23, 1655, stated that S. Lanckoronski gave 10 thousand people from Kisovonichintsi as the yasyr to the Tatars. Besides, the citizens of Makhnivka, Ialanivka, Sulpikhova, Skarodna, Kochubeyevka, Sukhaia Dibrova were given as the yasyr to the Tatars. In the letter to John Casimir, dated February 27, the Crimean khan wrote that he had sent envoys to the Cossacks and he insisted that they stopped fighting with the Russians. He also wanted the hetman to fight against the khan's enemies together with the Crimeans. In this letter Sefer Gazi wrote that he had sent three envoys to the Cossacks and proposed that they left the Russians. The letter from S. Rewera Potocki (dated June, 1655) announced the arrival of the kalga after the departure of Melin Sultan (Mengli Giray). The king instructed M. Jaskolski that it was necessary to command an audience with Mengli Giray Sultan and remind him of the Polish-Crimean alliance. The German leaflet dated 1656 referred to the letters of the khan addressed to the Polish king. In the summer of 1655 the Poles began negotiations with the Ukrainian hetman at the initiative of the khan. In 1656 Mehmed Giray wrote that Khmelnytsky sent an envoy to the Turkish sultan. In the autumn of 1655 the instructions to Romashkevich, the Polish envoy to Crimea, stated that the khan should influence Khmelnytsky, so that he would make peace. In November 1655, Nureddin Adil Giray sent his envoy Kamambet to Kamianets-Podilskyi to find out where the king was and where the Tatars had to unite with the Poles. Being under Galich, that month the khan wrote to the king that he fought with the Russians and Ukrainians near Solioni and devastated a large part of Ukraine. He promised to cover the land from Kamenka to Zborov with corpses. A little later it was reported that the Tatars smashed the Cossacks near Oserna, and that Khmelnytsky himself with the colonels asked the khan to accept him as a vassal of the Polish king. "The Letter of Prussia Affairs" quotes the Swedes saying that the Cossacks and the Tatars were Polish allies. The letter from a Vilnius governor from Konigsberg dated January 4, stated that the Cossacks and the Tatars should join the troops of Ian Casimir. In January 1656 the commander of Kiev army wrote to the king, saying that there was a 30-thousand army of Mengli Giray in Brazlawschtschyna. The troops included Nogai mirzas Kelimbet and Shakh. The instructions to Jan Shumovsky, the envoy from the king to the khan, indicated that the Zaporozhian Cossacks should be made loyal to the king and that Khmelnytsky should leave the Russians. It was also required to ensure that 10 thousand Tatars and 10 thousand Ukrainians came to help the Poles. In May 1656, Ian Casimir asked for help from the khan in order to defeat George Rakoczi. The German leaflet dated April 1656 mentioned the letters of the khan to the Polish king, as well as the negotiations between the Cossacks and the Tatars, aimed at getting help from their side. In MaySeptember 1656, it was claimed that in May the Cossacks attacked the Ural uluses of the Nogais. Envoys of Khmelnytsky, who sought the friendship of the Crimeans, arrived at the same time. The Ukrainian envoys also arrived in August and September 1656. In July 1656, the Turks and the Tatars opposed George Rakoczi. In August 1656 the khan sent 20 thousand Budzhakians against the Swedes. According to the German leaflet, after October 11, 1656, the victory of the Lithuanians and the Tatars over the Branderburgians and the Swedes in the battle of Prostki was announced. The same event is recorded in another German leaflet dated the same month [Mitsik, 2015, pp. 214, 221, 239-248, 315, 317-335].

In the letter of Islam Giray dated the second half of January, 1654, the khan accused the hetman of having changed the oath as he had no right to sign treaties with either foreign monarchs, or with his monarch, the Polish king, without the permission of the khan. He demanded that the hetman abdicate the oath given to Moscow. He called the allies to fight together against Moscow. 
In the letter of April 16, 1654, the hetman replied that the Tatars did not help the Cossacks during the talks near Kamyenyets. The Tatars looted a part of the Cossacks' possessions when they were returning from the campaign, and this left the Zaporozhian army in doubt. In addition, there were complaints from the hetman that he was in disgrace with the khan. It was also noted that, instead of making peace, Potocki fought against the Cossacks, and Gligorus Gurmas helped him to devastate the Cossack settlements. They invaded the Ukrainian lands up to Uman, but the Cossacks forced the Poles to withdraw. The hetman said that the alliance with Moscow had been formed following the advice of the Crimean khan, who had previously said the Poles were recruiting people from different regions to destroy the Cossacks. As for Smolensk and other cities that Moscow took away from the king, the hetman said he had not been aware of it. As for the fact that the Cossacks had captured the Tatars, it was said that they had been released. Semen Savich, the envoy of the Ukrainians to Crimea, should have provided more details about this. It was said that during the battle near Uman the Roman Catholic priest of Potocki was taken prisoner. It looked like Potocki did not want to fight, but he was forced by the king, who had sent Prince Karl to the war. Karl was supposed to get help from the Tatars. This information was confirmed in the letters from Lithuania, which the killed Pole had with him. The hetman asked the khan together with all the agas and the beys to fight against common enemies. The letter of Mehmed Giray IV to Bohdan Khmelnytsky said that Toktamysh Aga came to the Ukrainians. The hetman wanted the new khan to treat the Cossacks like Islam Giray did. In his letter, which was sent with Toktamysh, the khan threatened that if the Cossacks did not retreat from Moscow, he would set the Hungarians, the Multiians (Walachs) and the Walachs (Moldavians) against them. The Hetman said he had not broken the oath, but on the contrary, King Vladislav was punished for it. Bohdan said that he was not afraid of those whom the khan wanted to set on him, and he hoped for God, and not at all for Moscow. The hetman promised to be friends with the khan and asked to send some nobleman for the new contract. Toktamysh Aga should have given more detail to the khan. On November 2, 1655, the Zaporozhian army signed a new treaty with the Crimean Khanate. The hetman recognized Ian Casimir as his master and promised to retreat from Moscow. They agreed that the register could include more than 6 thousand people, and the hetman promised not to sign agreements with foreign countries without consulting with the Poles. Bohdan pledged to fight against the Swedes. In his letter dated January 31, 1656 it becomes clear that the hetman avoided all this with reference to difficult circumstances [Chukhlib, 2017, pp. 199-203, 206-210].

In the letter to Ian Vladislav Radziwill, dated January 9, 1657, Samuel Pashkovski wrote that the Russians, together with the Ukrainians and the Tatars, had destroyed all of Lithuania. The letter from Czestochowa, dated March 17, said that the Tatars were intent on attacking Transylvania again. In May 1657, it was said that the Tatars caused many losses to the Ukrainian lands at Chechelnik. In April 1657 the khan, the kalga and the vizier sent letters to Rzeczpospolita. In the document dated April 1657 Subkhan Kuli Aga was named the ruler of Budzhak. On May 30, it was reported that 3 thousand Cossacks closed the way to Moldova and Ukraine for the Tatars. Subkhan Gazi Aga wrote that the Ukrainians, the Hungarians, the Moldovans and the Walachs went to war against the Polish king. He declared his readiness to invade the Hungarian lands (Transylvania). The instructions to Romashkevich, dated May 1657, indicated that the khan was fighting against the Russians. The instructions to S. Benyovsky, the envoy from Rzeczpospolita to B. Khmelnytsky, indicated that it was necessary to make the hetman aware of the campaign of the Turks and the Tatars to Transylvania. The English leaflet dated August 15 mentioned that on August 15, the Tatars defeated the Transylvanians near Wyszniwczyk. The letter from Nikolai Salga to Andrzej Koniecpolski, dated the summer of 1657 said that the Tatars destroyed the 800 reiters of the electorate. The anonymous letter dated September 14, 1657, indicated that the Tatars devastated the Ukrainian cities on the borders with the Russian state. The letter from John Casimir to the Russian Tsar Alexei Romanov, dated October 17, 1657, said that the Tatars and the Turks were fighting against George Rakoczi. In October 1657, Artiemij Fiodorow, a government official, reported the attack of the Cossacks on Crimea and the Nogai uluses. 7 thousand Cossacks attacked Crimea and the Nogais. During the campaign the Cossacks lost a hundred warriors. They killed 15 thousand Tatars and took 5 thousand Tatars as the yasyr to Zaporizhia. They fought with the Tatar army near Perekop [Mitsik, 2015, pp. 337, 340-343, 345-347, 352-354, 356-358].

The French, especially G. de Tende and J.-B. Scherer, were interested in the events in Ukraine. 
J.-B. Scherer noted that in 1654 the Polish king paid 100 thousand gold to the Crimean khan Selim Giray to attack the Cossacks. But he died and his brother Mengli Giray who had invaded the Ukraine and defeated the Tomilenko's detachment rose to power. In 1655, it was reported that the Tatars and the Poles had attacked five colonels near Uman. Those were able to break the blockade. Then the Poles and the Tatars attacked Khmelnytsky near Dryzhipol. However, the victory was attributed only to the Ukrainians, and it was indicated that the Ukrainians fought their way to Bila Tserkva. Then there was a joint campaign with the Russians when their allied army reached Lviv, Lublin and Zamosc. Returning from the campaign, Khmelnytsky was confronted with the Tatars at Oserna. However, the khan could not defeat the Cossacks and decided to negotiate with them after sending 12 hostages to the Ukrainians. During the negotiations the Cossack hetman accused the Crimean khan of having broken the treaties with the Cossacks, having served the one who paid the most and having caused a lot of losses to the Cossacks. As the chronicle has it, he claimed he was ready to destroy Little Russia as soon as the khan of Astrakhan gave the promise. This made the Crimean khan angry, and he promised to destroy both the hetman and his army. In general, the text by J.-B. Scherer was not very different from the chronicle of G. Grabianki [Gaspard de Tende, 1697], [Scherer, 1994].

The information provided by this French historian had a number of inaccuracies; for example, the khans ruling the Tatars had completely different names. Cossack chronicles traditionally diminish the scale of the losses of the Cossacks and the role of the Crimeans in the conflict. Polish chroniclers essentially exaggerate the number of the Russians and the Ukrainians in the battle of Akhmatov.

Turk Mustafa Naima informed that the Liakhy (the Poles) sent a letter to the khan's vizier Sefer Gazi Aga, asking him to be an intermediary in the process of negotiating the peace treaty. He consulted with the khan and his entourage. It was pointed out that the Poles were exhausted over the sevenday siege, and Podolia was devastated. It was also stated that the power in the Liakh territory belonged to the beys, and that it was necessary to take two sons from the families of the noblest beys as amanats and demand tribute from them. The Poles were ready to fulfill any conditions of the Tatars. Liakh commanders left the camp and came to the Kamanice fortress. Sefer Gazi Aga, Katlaziush, bey of Shirins and ten agas arrived there as well. The Tatars demanded that they paid tribute, sent the sons of the two noblest beys as amanats and did no harm to the Cossacks. They also demanded that the Poles let the population of the villages and towns of the region be plundered, otherwise 100 thousand Tatars and Nogais together with 80 thousand Cossacks would be attacked again by Poland. Some of the Tatars, including Kaitas Aga and Kan Mehmed, were against signing a peace treaty with the Poles. They demanded that the negotiations be ceased and mullah Khani Aga, who had been taken hostage by the Poles, be released. However, the Poles accepted all the conditions of the Tatars, but they also said that it would be bad if the Cossacks robbed villages and towns. The Poles sent one son of a commander and a son of some governor as amanats. On December 15, 1653 , the peace treaty was signed. The Tatar and Cossack envoys returned to Vislaten (Husiatyn). The Tatars ruined the areas near the city of Dubno and Kart-Konstantin (Starokostiantyniv). Sefer Aga's son took Kart-Konstantin. Tatar Czambuls plundered the settlements on the Black Trail. In the spring of 1654, after they had gathered the yasyr, the envoy from the Poles arrived in rich clothing and on a luxurious horse, but with worthless gifts. In July 1654, khan Islam Giray III died. Then the Cossacks went to the Black Sea and devastated the shores of Varna and Eregli. Moreover, they attacked Balchik. Siyavush Pasha from Silistra was able to capture the crew of one boat. In late August Mehmed Giray IV departed from Turkey to Crimea. After arriving in 1655, he sent troops to the country of the Cossacks, which was his revenge for the raids on the Rumelian settlements. Then the khan easily seized the cities, took the people as the yasyr or killed them, following which he moved to the fortress, which was besieged by the Cossacks and the Muscovites. Then the siege was raised, and the Cossacks returned to their lands. When they retreated to the marshland, the Tatars slaughtered half of the 50 thousand Cossacks and 100 thousand Muscovites. It took the survived Muscovites three days to move from the battlefield. There, the Tatars attacked them again, and 5 thousand out of 30 thousand Muscovites died. The Tatars then returned to their lands and met an embassy of 500 Muscovites there. They brought the news that the Swedish king had captured the country of Liakhs. In January-February of 1655-1656, it was decided to snatch the country of Liakhs from the hands of the Swedes. Naturally, the Turkish chronicler overstated both the number of the enemy troops and the Crimeans [Naima, pp. 164-172]. 
According to diplomatic documents, the Crimean khan asked the Poles not to start the campaign without the Crimeans. In December 1654, the Crimean envoy, who visited Rzeczpospolita, mentioned 50 thousand Tatars who were ready to march off to attack Moscow. The Crimean Mirza demanded not to destroy the Cossacks. In January 1655 they set off toward Ukraine. In the same year the Kalmyks negotiated citizenship with the Russians and planned to fight together with the Don Cossacks against the Crimeans. The actions of the Kalmyks were limited to the actions against the Kasaevs (the remnants of the Little Nogai Horde) in the Terek area. In fact, the Russians and the Ukrainians opposed the alliance of the Crimeans with the Poles. The Polish envoy Korycki agreed with the Budzhak Nogais on their march to Ukraine. In early December they stood at the Dniester, waiting for the river to freeze, so that they could walk on the ice near Rascov. A. Radziwill reported that the Crimeans united with the crown army in December 1654. On January 1, 1655, the Poles joined the Tatars. During the winter campaign B. Khmelnytsky used diplomacy and money to persuade the Crimeans not to participate in the battle of Akhmatov on January 19-22, 1655. The hetman influenced the khan with the help of the mirzas, who were close to the late Islam Giray III. It should be noted that Mehmed Giray IV suggested B. Khmelnytsky renouncing the alliance with the Russians in order to remain an ally of the Crimeans as far back as October 1654. Near Akhmatov the Poles were the only ones who acted more proactively and besieged the camp of the Russians and the Ukrainians. The victory in this battle was gained thanks to the fact that I. Bohun had attacked the enemies from the rear and approached them from Uman. Without joining the battle, the Crimeans retreated, taking the yasyr from Kyiv and Bratslav regions with them. The events that occurred near Dryzhepol allowed launching the general offensive to the west. The Russian troops advanced westward from the territories of the Grand Duchy of Lithuania, reaching Grodno and Vilnius. Along with Russian auxiliary forces, the Cossack detachments invaded the crown lands and came to Galicia through Volhynia and Podolia. In the battle at Gorodok in September-November they defeated the troops of S. Potocki, and then besieged Lviv. The defeats of Rzeczpospolita became a signal for the Swedes, who invaded Poland in the summer of 1655 [Fedoruk, 2011, pp. 83-86, 91-96], [Litopis gadiatskogo...], [Velichko], [Grushevskii], [Cofonovich], [Podhorodecki, pp. 190-194].
In 1655, the Crimean khan Mehmed Giray IV sent a number of his embassies to Europe. The Crimean embassy set off at the end of December of 1654 or in early 1655 . The embassy was headed by Maidan Gazi Bek. They traveled to Austria through Rzeczpospolita, since the Transylvanian governor was hostile to the Poles at that time. It should be noted that Ian Casimir ordered his people to accompany the Tatars to the Austrian border. On February 27, the Austrian emperor granted an audience to the Crimean envoy. This event was reported by English and German newspapers. The Tatar envoy presented the Kaiser with a horse, which cost 1000 ducats and was surprisingly enduring. On March 1, the Kaiser granted a farewell audience to the Crimean envoy and presented him with a gold chain and 1,400 ducats for the return journey. The Crimeans reported to the Austrians on Mehmed Giray IV becoming the new khan, and on the friendship with the Austrians. It was suggested that imperial troops be sent to help the Poles. The Dutch resident in Vienna pointed out that the khan demanded financial or any other support for Rzeczpospolita from the Kaiser. The Polish envoys said that the Polish army should unite with the Tatars in the near future and that they would invade the provinces occupied by the enemy [Fedoruk, 2010, pp. 45-46].

In the same year, the embassy arrived in Denmark (at the end of December 1654 - July 1655). There are no documents left about the contacts in the Royal Danish Archive, but their drafts have been preserved. These were the replies to the proposals from the Tatars. The Crimean embassy to Denmark shared with the desire of Rzeczpospolita to oppose the Danes to the Swedes. According to the Danish response to the Crimeans, it can be concluded that the Danish king received six letters from the Crimean khan, his main wife, the kalga Gazi Giray, the nureddin Adil Giray, the vizier Sefer Gazi Aga and the treasurer Dzhan Mirza Aga. The khan wrote to the king that he had formed an alliance with Ian Casimir and offered him to respect the Polish king as he did. J. Leszczynski, the Lenchitsky commander of the army, mentioned the Danish skipper carrying the Tatar envoy. The answer of the Danish king to the Crimeans was written on June 20 (30), 1655. The Crimean envoy was to arrive in Denmark in the middle or in the second half of May. Having returned to his capital on June 8 (18), the Danish king Frederick planned to grant an audience to the Crimeans. At this audience the Crimean envoy re- 
ported the ascension on the throne of Mehmed Giray IV and assured him of friendship. The khan planned that Denmark would participate in the anti-Russian coalition. Swedish diplomatic official Magnus Durelle reported that the khan had offered the Danes to attack the Russians from the sea from Norway. On June 30 (July 10) the Crimean envoy received the answer that Denmark had no reason to fight against the Russians. In addition, the Crimean envoy asked the Danes to influence Sweden to make peace with Rzeczpospolita. This was mentioned in the letter of $\mathrm{K}$. Tyszkiewicz to $\mathrm{J}$. Radziwill. The Crimean khan demanded that the Poles negotiate with the British and the Dutch. On May 19, 1655, the Polish embassy went to the Netherlands, meeting the requests of the khan. After June 20 (30), the Crimean envoys spent another month in Copenhagen. English newspapers reported that the Tatars were ready to return and they were just waiting for the Danish king to give the order. In late July, the Crimean envoys left Denmark and returned through Rzeczpospolita, meeting with John Casimir [Ibid., pp. 42-44].

In 1655, the Crimeans sent envoys with numerous documents to Sweden. They discussed friendship and alliance with Ian Casimir with the Swedes. V. Benyovsky reported that Jan Casimir initiated the embassy to Sweden, so that the Swedes would not think of attacking Rzeczpospolita. In addition, the Crimeans agreed on their contacts with the Scandinavian countries and the government of the Ottoman Empire. The Crimean envoy brought letters from the khan, the kalga Gazi Giray, the nureddin Adil Giray, the khan's main wife, the vizier Sefer Gazi Aga, Timur Aga, the son of Bakhadir Giray, Mekhmed Giray, Ali Gazi Aga, Abdullah Kerim Aga, the khan's secretary and Dzhan Mirza Aga. Adilshakh Mirza delivered the khan's letter to the Swedish king, and Ali brought the letter from the khan's wife, Murtaza delivered the letter from the nureddin, Khassan came with the letter from the khan's secretary, and Gizel delivered the letter from Bakhadir Giray's son. German chronicler Johann Georg Schleder pointed out that the Crimean embassy included 17 people. The envoys were given instructions to set the Swedes against the Russians. The Polish king ordered that Pan Iukhno together with G. Kanazilii, the former Polish envoy to Sweden, accompanied the Crimean envoys to Gdansk.

The French resident in Sweden reported that the Crimean embassy arrived at the end of January 1655. The Swedish diplomatic official I. Eckelbad reported that the Tatars reached Stockholm on May
9 (19), 1655, and the Danish residents in Sweden reported on the embassy from the Perekop (Crimean) khan to the Swedish king. It should be noted that the Crimeans informed about the ascension on the throne of Mehmed Giray IV and congratulated Karl X Gustav on his accession on the throne. On May 16 (26), 1655, the Crimeans received an audience with the Swedish king. On May 22 (June 1), Swedish Chancellor E. Oxenshiern held negotiations with them. Adilshakh Mirza tried to convince the Swedes of the khan's good intentions and the need to maintain peace with Rzeczpospolita. On the same day the Swedish king responded to the Crimeans. On June, 24 they received a farewell audience, and on July, 5 the Crimean envoy, having received gifts from the king, set off to its return journey. In the correspondence of the Crimean khan with the Swedish king there was a proposal to create an anti-Russian league with the help of the Crimean Khanate, Rzeczpospolita and Sweden. In turn, Karl X Gustav wrote that an alliance with the Poles was impossible because in the past Sigismund III and Wladyslaw IV from the Vasa dynasty had claimed unreasonably to become Swedish kings. It was also noted that Queen Christina wanted to resolve the contradictions with the Poles, but had not succeeded in doing so. The Swedish king noted that the Crimean khan was aware of the Polish-Swedish contradictions. The correspondence materials of Sigismund III and Wladyslaw IV with the Crimean khans enable us to conclude that the Crimean khans were well aware of the claims of these kings and, trying to make an alliance with Rzeczpospolita, included the title of the Swedish king into the title of the king of Rzeczpospolita. The Swedes asked the Crimeans not to attack the Ukrainian Cossacks and to resume their alliance with them. By and large, the Crimean embassy was unsuccessful in 1655 [Fedoruk, 2010]. Having joined the alliance with the Russians in Pereyaslav, the Ukrainians from the Hetmanate tried to establish peace with the Tatar khan. In February-April 1654, the embassy of S. Savich headed to Crimea, and in August 1654, the embassy of P. Teteri started its journey [Chukhlib, 2010]. In 1657, the Tatars renewed confrontation with the Ukrainians. They occupied many cities in border regions. The hetman's attempt to neutralize the Crimeans was unsuccessful. At that time the Crimeans made peace with the Russian tsar. In March 1657, the embassy of Larion Kapusta was sent to Istanbul. The letter to the janissarian Aga said that the hetman formed an alliance with the Crimean khan, but this was not the case. Meanwhile, Rzeczpospolita 
made an alliance with the Habsburgs and Denmark. The reason behind this was the invasion of the Swedes and the Transylvanians, as well as the intention of the Russians to make Western Ukrainian lands a part of their state [Chukhlib, 2017, pp. 46-52].

The Crimean khans should have been sanctioned by the Ottomans because of the conflict with Transylvania. Mehmed Giray IV obtained this permission in 1657. In 1655 George II Rakoczi adopted a wait-and-see attitude and offered the Poles to be their intermediary in negotiations with the Cossacks. The defeat of the Poles in the battle of Akhmatov made George II Rakoczi declare his hostility towards Rzeczpospolita. In 1656 he entered the alliance with Sweden and the Hetmanate against Rzeczpospolita. The participation of the Hungarians in the war against Rzeczpospolita in early 1657 was not coordinated with Istanbul, so the khan was able to fight against Transylvania. It must be noted that the war of Denmark against Sweden in 1657 and the Russian-Swedish war forced the Swedes to transfer their troops from Poland to other directions. The troops of George II Rakoczi, which had previously been near Krakow and Warsaw, were forced to retreat from Poland. The Transylvanian army and the troops of A. Zhdanovich were overtaken by S. Czarniecki near Maheriw on July 11, 1657. The Ukrainians retreated, not entering the battle, and the Transylvanians defeated the main forces of the Poles, who attacked the Hungarians when they repelled the attack of the Polish avant-garde on their camp. After this victory the troops of A. Zhdanovich left the Transylvanian prince and quickly retreated. S. Czarniecki united with the troops of S. Potocki and J. Lubomirski. Moreover, the Crimean army was coming to join them [Sanin, 2005, pp. 100-125], [Fedoruk, 2011, pp. 90-91], [Litopis gadiatskogo ...], [Velichko], [Cofonovich].

In 1655, Swedish and Transylvanian diplomatic officials tried to break the alliance between John Casimir and the Crimeans, but Nureddin Adil Giray appeared near Galich, and thanks to the help of the Tatars, the Poles kept Lviv. Patrick Gordon, a Scot, preserved some information on the collision of the Transylvanians and the Crimeans. He reported that in 1657, when it became known that the Crimeans were approaching, the Cossacks spread across Ukraine, while the Transylvanian prince capitulated to the Poles and pledged to pay them a contribution for the losses he had caused [Gordon].

J. Jerlicz reported that in 1656 the Tatars devastated Podlachia, came to Prussia, took 100 thou- sand Germans and Swedes as their yasyr, and the Swedish commander retreated. As regards 1657, it was reported that the Cossacks separated themselves from the Transylvanian prince near Chornyi Ostriv where the Tatars had defeated him. 400 Hungarians fled to Sapieha from all the troops, while Rakoczi and Kemen stayed alive [Erlicz, p. 186].

Speaking of the events of 1656-1657, Mustafa Naima reported that wicked Rakoczi wanted to occupy the Liakh lands and formed an alliance with the governors of Bogdan (Moldova) and Efliak (Wallachia). He headed the march of 60 thousand people and became an ally of Sweden. When he learned that the khan had come out against him with an incalculable Tatar army, he set up a camp, protected by ditches. When the Khan sent 100 thousand Tatars to ravage Erdel (Transylvania), the land of Rakoczi, he decided to defend his country and fled from the camp. The army without the governor was defeated by the Tatars. The Tatars also destroyed many settlements in Erdel [Naima, pp. 172-174].

Samovidets wrote that in 1657 the Hungarians of Rakoczi were attacked by the Tatars together with the Poles, who came from Podgorje to Medzhybizh. It was noted that the Poles, who found themselves in a difficult situation, asked the khan to help them. The Crimeans came to the rescue through the lands of Moldavia and the region of Podgorje (through Galicia and Lesser Poland). Khmelnytsky sent his son Iuri to help them, but he headed back as soon as he learned that Rakoczi had already been defeated [Litopis Samovidtsia].

S. Velichko reported that the Poles and the Tatars, led by Gosiewski, defeated the Swedes in the battle of Prostki, taking three generals prisoner. The Tatars killed the adviser to the Swedish king. The Poles and the Tatars defeated the troops of the Brandebug-Prussian elector near Warmia. These events, as well as the Vilna truce and the entry of Denmark into the war, forced the Swedes to retreat. The Prussians withdrew from the war along with the Poles, the Swedes recalled the troops from the Russians and began to withdraw their troops from Rzeczpospolita. These circumstances complicated the situation for George Rakoczi, while the invasion of Lubomirski's and Austrian troops into the Transylvanian lands came as an unpleasant surprise. The Hungarians began to retreat, and the Poles, headed by Czarniecki, defeated them under Maheriw and Kulikov. George Rakoczi retreated to Zborov, then to Chornyi Ostriv. There, Czarniecki and Sapieha attacked him, and the Transylvanian 
prince was forced to abdicate the Polish throne, while Zhdanovich's troops had abandoned the Hungarians even before the battle [Velichko].

It was reported that the Tatars did not make peace with the Hungarians, but attacked them. The army of George Rakoczi lost 5 thousand people, and Janusz Kemen was captured by the Crimeans. The army of George II Rakoczi comprised 13 thousand Hungarians, 6 thousand Moldovans and Walachs. G. Sanin insisted that there were 20 thousand Hungarians, 6 thousand Walachs and Moldovans in the army. Evlia Celebi reported on 60 thousand Hungarians, which is, undoubtedly, a great exaggeration. He indicated that there were 80 thousand Tatar soldiers. Ten carts were said to be full of wallets brought to the Tatars from Gdansk. The Turkish chronicler mentioned that George II Rakoczi had escaped, and noted that the courageous J. Kemen had chained the camp trying to defend himself. The Crimeans did not immediately help Rzeczpospolita, since in the winter of 16561657 there was a death of cattle, and the Don Cossacks attacked the lands of the Khanate. The Crimean khan then organized the siege of the city of Cherkessk and sent aid only in the spring. Soon the Transylvanian prince left the army, and it was ruled by J. Kemen [Sanin, 2005, pp. 100-125], [Evlia Celebi].

P. Gordon reported that the Hungarians were encircled by 60 thousand Crimeans. A strong pressure was put on the army of J. Kemen, but the Hungarians defended themselves with the wagenburg bravely defeating the Tatars with muskets and cannons. The Tatars massively attacked the enemies with bows, inflicting losses on them. Many animals were slaughtered, and they ran out of food supplies near Medzhybizh. The Moldavians fought most bravely in the Transylvanian troops, but when the Tatars pretended to be the Turks, the Moldavians became confused and rebelled. The army of J. Kemen capitulated after the Crimeans promised them to let them go home. However, as soon as the Hungarians opened the rows of carts, the Crimeans attacked them [Gordon].

The Hungarians fought bravely, but were defeated, and 275 noble people were captured. They were bought for 123 thousand gold. 23 people did not return to Transylvania from captivity. As for the total number of prisoners, there were about 4 thousand people. J. Kemen was not confirmed to be the prince of Transylvania, because he was a prisoner of the khan. M. Apafi took over the ran- som of the prisoners and later became the prince [Ivanich, pp.126-134].

The policy of the Crimean Khanate was aimed at maintaining the balance of power in Eastern Europe. The relations between the Crimean Khanate and Ukraine (Hetmanate) were quite complex. The separate peace treaty with Rzeczpospolita at the end of 1653 led to the separation from the Ukrainians, which, however, was not final. In the campaign of 1654-1655, the Crimeans did not allow the defeat of B. Khmelnytsky near Akhmatov, who was able to negotiate with Mohammed Giray IV. Even the encirclement of the Ukrainians by the khan's army near Oserna did not lead to the defeat of the Ukrainians, and the khan and the Ukrainian hetman held active negotiations. The khan took the chance to negotiate with B. Khmelnytsky. The Crimeans fought against other enemies of Rzeczpospolita in full force. In the battle of Prostki, the Crimeans helped the Poles defeat the Swedes, and the raid on Prussia forced the local ruler to end the active war against the Polish king. The battle with the troops of George II Rakoczi led to the complete defeat of the Hungarians.

\section{References}

Chernigovskaia letopis [Chernigiv Chronicle]. (1856). Iuzhnorusskie letopisi. Kiev. URL: http://litopys.org.ua/bilozer/bilz01.htm (accessed: 20.01.2019). (In Ukrainian)

Chukhlib, T. (2010). Kozaki ta ianichari. Ukraïna v khristiians'ko-musul'mans'kikh viinakh 1500-1700 rr. [The Cossacks and the Jannisaries. Ukraine in ChristianMuslim wars, 1500-1700]. 446 p. Kiev, VD KiïvskoMogilianska Akademiia. (In Ukrainian)

Chukhlib, T. (2017.) Kozaki i tatari. Ukraïns'kokrims'ki soiuzi 1500-1700-kh rokiv [The Cossacks and The Tatars. Ukrainian-Crimean Alliances, 1500-1700]. 274 p. Kiev, VD Kievo-Mogilianska akademiia. (In Ukrainian)

Cofonovich, F. (1992). Khronika $z$ litopistsiv starodavnikh [Chronicle from Ancient Manuscripts]. 336 p. Kiev, Naukova dumka. (In Ukrainian)

Erlicz. (1853). Latopisiets albo Kroniczka Joachima Jerlicza [Erlicz. The Journalist or the Chronicler Joachim Jerlicz]. Vol. 1. Warszawa, W drukarni Wienhoebera. URL: http://books.google.com.ua/books? $\mathrm{id}=$ tkghAQAAMAAJ $\&$ printsec $=$ frontcover $\& \mathrm{hl}=\mathrm{uk} \&$ so urce $=$ gbs_ge_summary_r $\&$ cad $=0 \# \mathrm{v}=$ onepage $\& \mathrm{q} \& \mathrm{f}=\mathrm{fal}$ se (accessed: 20.01.2019). (In Polish)

Evliia Chelebi. (1961). Kniga puteshestviia (Izvlecheniia iz sochineniia turetskogo puteshestvennika XVII veka) [A Traveller's Book (Extracts from the Turkish Traveller's Essay of the $17^{\text {th }}$ Century)]. Zemli Moldavii i Ukrainy. Moscow, Vostochnaia literatura, Nauka, No. 1. URL: http://www.vostlit.info/Texts/rus8/ 
Celebi3/text3.phtml?id=1729 (accessed: 20.01.2019). (In Russian)

Fedoruk Ia. (2010). O. Posolstva Krimskogo khana Megmeda Gireia do Shvetsiï, Daniï ta Avstrï u 1655 r. [The Embassies of the Crimean Khan Mekhmed Giray to Sweden, Denmark and Austria] Ukraïnskii istorichnii zhurnal. Kiïv, No 5, pp. 37-50. (In Ukrainian)

Fedoruk, Ia. (2012). Politika Krimskogo khanstva v Okhmativskii kampanii 1654-1655 rr. [Policy of the Crimean Khanate in the Akhmatov Campaign 16541655]. Chornomorska minuvshchina. Odessa, No. 2, pp. 3-11. (In Ukrainian)

Fedoruk, Ia. (2011). Ukraïnsko-polska viina v polititsi Krimskogo khanstva, Rosiï i Pridunaiskikh kniazivstv (kinets 1654 - pochatok 1655 rr.) [UkrainianPolish War in the Policy of the Crimean Khanate, Russia and Danube Princedoms]. Problemi istoriï kraïn Tsentralnoï ta Skhidnoï Evropi. No. 2. Kiïv, pp. 83-100. (In Ukrainian)

Gaspard de Tende - Das Bey noch zweiffelhaffter Wahl eines neuen Königs ganz Verwirrte und Unruhige Polen: Worinnen Zugleich von dieser Republique Stärcke und Schwäche, Vortheile und Mängel absonderlich von der Eingeschränckten Gewalt Ihrer Könige ... umbständlich gehandelt wird: Vorhero in Französischer Sprache beschrieben, anjetzo ... in das Hochteutsche übersetzet. (1697). 172 p. Coln, Pierre Matheau, URL: http://books.google.com.ua/books?id= 6D9NAAAAcAAJ\&printsec=frontcover $\&$ hl=uk\&sourc e=gbs_ge_summary_r\&cad $=0 \# \mathrm{v}=$ onepage $\& \mathrm{q} \& \mathrm{f}=$ false (accessed: 20.01.2019). (In German)

Gordon, P. (2001). Dnevnik 1635-1659 [Diary 1635-1659]. Vol.1. Moscow, Nauka. URL: http://www.vostlit.info/Texts/rus13/Gordon/frametext3. htm (accessed: 20.01.2019). (In Russian)

Grushevskii, M. S. (1997). Istoriia Ukrä̈ni-Rusi [The History of Ukraine-Russia]. 776 p. Vol. 9. B.2. Kiev, Naukova dumka. URL: http://litopys.org.ua/ hrushrus/iur9.htm (accessed: 20.01.2019). (In Ukrainian)

Historia o buntach Chmielnickiego, o woinie $z$ Tatarami, ze Szwedami $i$ z Wegrami za króla Władystawa IV $i$ za Jana Kazimierza przez lat dwanaście, krótko zebrana, ab anno 1647, anno 1648 [The Story about Khmelnytsky's Riots, about the War with the Tartars, with the Swedes and Hungarian King Władysław IV and John Casimir]. URL: http://pbc.gda.pl/dlibra/doccontent?id=6295\&from=FB C (accessed: 20.01.2019). (In Polish)

Ivanich, M. (2005). Transilvanskie plenniki v Krymskom khanstve v 60-e gody XVII veka [Transylvanian Captives in the Crimean Khanate in the 1660s]. Gosudarstvennost, diplomatiia, kultura v Tsentralnoi i Vostochnoi Evrope. Moscow, pp. 126-134. (In Russian)

Kochowski, Wespazjan. (1859). Historia panowania Jana Kazimerza [History of the Reign of John Casimir]. Vol.1. Poznan, Nakladem i Czcinkami N. Kamienskogo i spolki. URL: http://dir.icm.edu.pl/pl/
Historia_panowania_Jana_Kazimierza/Tom_1/

(accessed: 20.01.2019). (In Polish)

Kolodzejczyk, D. The Crimean khanate and Poland-Lithuania: international diplomacy on the European periphery (15th-18th century): a study of peace treaties followed by annotated documents. Leiden-Boston: E. J. Brill, 2011. XXXVI, 1109 p. (In English)

Kratkaia istoriia o buntakh Khmel'nitskogo $i$ voine $s$ tatarami, shvedami $i$ ugrami $v$ tsarstvie Vladislava $i$ Kazimira, v prodolzhenii dvenadtsati let, nachinaia $s$ $1647 \mathrm{~g}$. [A Brief History of the Khmelnytsky's Riots and the War with the Tatars, the Swedes and the Hungarians in the Kingdom of Wladislaw and Casimir, which Lasted for Twelve Years, Starting in 1647]. Chteniia v Imperatorskom obshchestve istorii i drevnostei rossiiskikh pri Moskovskom universitete. No 4. Moscow, 1846. URL: http://litopys.org.ua/samovyd/ sam12.htm (accessed: 20.01.2019). (In Russian)

Lizogubivskii litopis [Lyzogub chronicle]. (1888). Sbornik letopisei otnosiashchikhsia $\mathrm{k}$ istorii Iuzhnoi i Zapadnoi Rusi. Kiev. URL: http://litopys.org.ua/ sborlet/sborlet02.htm (accessed: 20.01.2019). (In Ukrainian)

Litopis gadiatskogo polkovnika Grigoriia Grabianki [Chronicle of Gadiatski colonel Gryhori Grabianka]. (1992). 192 p. Kiev, T-vo Znannia Ukraïni. URL: http://litopys.org.ua/grab/hrab.htm (accessed: 20.01.2019). (In Ukrainian)

Litopis Samovidtsia [Samovidets Chronicle]. (1971). 208 p. Kiev, Naukova dumka. URL: http://litopys.org.ua/samovyd/sam.htm (accessed: 20.01.2019). (In Ukrainian)

Malov, A. V. (2006). Russko-polskaia voina 16541667 [Russian-Polish War, 1654-1667]. 50 p. Moscow, Tseikhgauz. (In Russian)

Costin, Miron. Letopisețul Țărîi Moldovei de la Aaron Vodă încoace. URL: https://ro.wikisource.org/wiki/ Letopise\%C8\%9Bul_\%C8\%9A\%C4\%83r\%C3\%AEi_ Moldovei_de_la_Aaron_Vod\%C4\%83_\%C3\%AEncoac e (accessed: 20.01.2019). (In Polish)

Mitsik, Iu. A. (2015). Dzherela $z$ istorii Gatsionalno-vizvolnoï viini (1655-1658) [Sources on the History of the Liberation War (1655-1658)]. 540 p. Vol. 4. Kiev, Institut ukraïnskoï arkheografiï ta dzhereloznavstva im. M. S. Grushevskogo. (In Ukrainian)

Mitsik, Iu. A. (1984). Litopisets Dvoretskikh pamiatnik ukrainskogo letopisaniia XVII v. [Chronicle of Dvoretskie as the Monument of Ukrainian History of the $17^{\text {th }}$ Century]. Khroniki i letopisi 1984. Moscow. URL: http://litopys.org.ua/samovyd/sam15.htm (accessed: 20.01.2019). (In Russian)

Naïma, Mustafa. (2016). Giuseinovi gorodi $u$ vitiagu istorii iz zakhodu ta skhodu [Gussein's Cities in the History from the West and the East.]. 288 p. Kiev, Vid-vo Zhupanskogo. (In Ukrainian)

Pernal, A. B. (2013). Rich Pospolita dvukh narodiv i Ukraïna.Diplomatichni vidnosini 1648-1659 rr. [The Commonwealth of Two Nations and Ukraine. Diplo- 
matic Relations, 1648-1659]. 400 p. Kiev, VD KiïvskoMogilianska Akademiia. (In Ukrainian)

Podhorodecki, L. (1987). Chanat Krymski i iego stosunki s Polska [The Crimean Khanate and its Relations with Poland]. 359 p. Warszawa, Książka i wiedza. (In Polish)

Sanin, G. A. (1987). Otnosheniia Rossii i Ukrainy s Krymskim khanstvom $v$ seredine XVII v. [Relations of Russia and Ukraine with the Crimean Khanate in the Middle of the $17^{\text {th }}$ Century]. 270 p. Moscow, Nauka. (In Russian)

Sanin, G. A. (2005). Rossiia, Ukraina, Transil'vaniia $v$ sisteme mezhdunarodnykh otnoshenii serediny XVII v. [Russia, Ukraine, Transylvania in the System of International Relations in the Middle of the $17^{\text {th }}$ Century]. Gosudarstvennost, diplomatiia, kultura $\mathrm{v}$ Tsentralnoi i Vostochnoi Evrope. Moscow, pp. 100125. (In Russian)

Sherer, Zh. B. (1994). Litopis Malorosï abo krä̈ni kozakiv-zaporozhtsiv ta kozakiv Ukraïni, abo Malorosii [Chronicle of Little Russia and Countries of Zaporozian Cossacks and Cossacks of Ukraine (Little Russia)]. 311 p. Kiev, Ukraïnskii pismennik, URL: http://litopys.org.ua/scherer/sher03.htm (accessed: 20.01.2019). (In Ukrainian)

Smolii, V., Stepankov, V. (2009). Ukraïnska natsionalna revoliutsiia XVII st. (1648-1676) [Ukrainian National Revolution of the $17^{\text {th }}$ Century, 16481676]. 447 p. Kiev, VD Kiïvs'ko-Mogilians'ka Akademiia. (In Ukrainian)

Twardowski, S. (1681). Woina domowa z Kozaki, Tatary, Moskwa, potym szwedami $i$ zegry przez lat dwanascie za panowania Nayiasnieyszego Jana Kazimierza Krola Polskiego [Civil War with the Cossacks, the Tatars, Moscow, the Swedes and the Hungarians for Twelve Years during the Reign of John Casimir, the King of Poland]. Calissii, Typ. Collegii Callissiensis. URL: http://books.google.com.ua/books? $\mathrm{id}=\mathrm{yk} 0 \_A A A A c A A J \&$ printsec $=$ frontcover $\& \mathrm{hl}=\mathrm{uk} \&$ sou rce $=$ gbs_ge_summary_r \&cad $=0 \# \mathrm{v}=$ onepage $\& \mathrm{q} \& \mathrm{f}=\mathrm{false}$ (accessed: 20.01.2019). (In Polish)

Velichko, S. V. (1991). Litopis [Chronicle]. 371 p. Vol. 1. Kiev, Dnipro. URL: http://itopys.org.ua/ velichko/vel.htm (accessed: 20.01.2019). (In Ukrainian)

\title{
ВОЕННЫЙ АСПЕКТ СОЮЗА МЕЖДУ РЕЧЬЮ ПОСПОЛИТОЙ И КРЫМСКИМ ХАНСТВОМ В 1654-1657 ГГ.
}

\author{
Ярослав Валентинович Пилипчук, \\ Национальный педагогический университет им. М. П. Драгоманова, \\ Украина, 03037, ул. Освиты (Просвещения), д. 6, каб. 24, \\ bachman@meta.ua.
}

\begin{abstract}
В данной статье рассмотрен вопрос о военных и дипломатических аспектах союза Крымского ханства с Речью Посполитой в 1654-1657 гг. В 1654 г. произошло переформатирование системы международных отношений в Восточной Европе. Переход Гетманщины под протекторат Русского государства обусловил тесное сотрудничество между династиями Гиреев и Ваза. Переход крымских татар на сторону поляков вынудил перейти запорожцев к обороне. Избегнуть поражения около Ахматова в 1655 г. русско-украинскому войску удалось благодаря дипломатическому таланту Б. Хмельницкого, удачному наступлению И. Богуна и нежеланию Мехмеда-Гирея IV и крымских мирз допустить окончательную победу одной из сторон. Битва под Озерной в 1655 г. стоила украинцам значительных потерь. Помощь крымских татар полякам под Простками и Черным Островом обусловила поражение брандербуржцев и трансильванцев соответственно. Через польские контакты крымцы отправили посольства в Австрийскую империю, Данию и Швецию. Попытка привлечь Данию и Швецию к антирусской коалиции были неудачными. Кампания крымцев в 1657 г. против трансильванцев была санкционирована Османами.
\end{abstract}

Ключевые слова: Речь Посполитая, Гетманщина, крымские татары, Крымское ханство, международные отношения, Гиреи.

Одним из знаковых событий в истории Восточной Европы был договор между русскими и украинцами в 1654 г., известный как Мартовские статьи. Гетманщина переходила под протекторат Русского государства (Московии) и получала широкую автономию. Это событие привело к переформатированию коалиций в
Восточной Европе. Настоящее исследование посвящено военному союзу Речи Посполитой с Крымским ханством, столкновениям татар с украинцами, трансильванцами и шведами. Данный аспект был освещен в первую очередь в исследованиях польских исследователей Д. Колодзейчика [Kolodzejczyk] и Л. Подхородец- 
ки [Podhorodecki]. Среди русских исследователей этот вопрос поднимали Г. Санин [Санин, 1987] и А. Малов [Малов], среди украинских этой проблемой занимаются Я. Федорук [Федорук, 2010], [Федорук, 2011], [Федорук, 2012], В. Смолий, В. Степанков [Смолій, Степанков], Т. Чухлиб [Чухліб, 2010], [Чухліб, 2017]. Задачей данной работы является исследование военного и дипломатических аспектов союза Крымского ханства с Речью Посполитой в 1654-1657 г.

Вопрос о польско-крымском союзе более всего освещен в дипломатических документах. В декабре 1653 г. велись переговоры между крымцами Сефер-Гази-аги и поляками. 15 декабря было достигнуто Жванецкое соглашение, по которому Ян-Казимир подтверждал условия Зборовского мира, выплачивал хану 200 тыс. талеров и обещал давать упоминки в 30 тыс. талеров ежегодно. Несмотря на то что в Жванецком соглашении были пересмотрены условия тяжелых для казаков украинско-польских договореностей под Белой Церковью, Б. Хмельницкий решил изменить внешнеполитический курс и заключил союз с русскими, что привело к изменению системы политических отношений [Перналь, с. 118-120], [Літопис гадяцького полковника Григорія Грабянки], [Грушевський], [Софонович], [Podhorodecki, c. 182$186]$.

18 июля 1654 г. Ян Казимир заключил мир с Крымским ханством. В Варшаву на заседание сейма прибыл крымский посол Сулейман-ага. Король Речи Посполитой и хан Крыма и далее продолжали называться пышными титулами. Упоминалось о давних традициях дружбы между государствами, а также как давнее обязательство Речь Посполитая обещала платить упоминки. Говорилось, что во владения королевства вторглись московский царь с казаками. Объектом вторжения названы земли Великого Княжества Литовского. Крымский хан и его преемники обязывались предоставить полякам помощь: не заключать сепаратного мира с русскими и запорожцами. Указывалось, что когда казаки и население Украины вернутся под власть Речи Посполитой, то король не допустит с той стороны набегов, которые послужили бы причиной для войны. Указывалось, что поляки согласны быть друзьями вассалам Османской Империи - трансильванскому князю Дьёрдю Ракоци II, господарям Молдавии и Валахии. В документе от 20 июля 1654 г. Ян Казимир обещал, клянясь на Евангелии, воевать против русских, поддерживая дружбу с Исламом-Гиреем и подчинявшимися ему ордами. Тем же числом датирована присяга сенаторов быть в дружбе и заключить союз с Исламом-Гиреем против русских. Заключив с Русским государством договор, Богдан Хмельницкий хотел сохранить хорошие отношения с Крымским ханством. Украинские послы в Стамбуле просили султана позволить хану сохранить мирные отношения с запорожскими казаками. Хмельницкий написал письмо Исламу-Гирею, в котором обещал вечную дружбу. Крымский везир Сефер-Гази-ага обвинял гетмана в том, что он заключил договор с русскими. В мае 1654 г. в Чигирине пребывал крымский посол, который вернулся в Крым в начале июня. Летом татарские войска стали готовиться к вторжению на Гетманщину. В августе умер Ислам-Гирей, что несколько отложило вторжение. Новый хан послал к гетману своего эмиссара Камамбет-мирзу, предлагая союз, но требуя оставить русских. В ответ на это гетман отправил посольство в Крым во главе с Михаилом Богаченком. В октябре Мехмед-Гирей начал угрожать гетману. В том же году состоялись переговоры с крымским послом Токтамыш-агой. В январе 1655 г. во время похода крымцев на Украину у Ахматова состоялся новый раунд переговоров. Тогда же гетман получил предложение Карач-бея и части султанов с предложением союза против поляков, но при условии разрыва с русскими. 12 ноября 1655 г. украинцы и крымцы заключили перемирие под Озерной. Гетман, находясь в сложном положении, был вынужден подписать крайне невыгодный договор. Впрочем, Богдан Хмельницкий серьезно и не пытался его выполнять. В январе 1656 г. он вел переговоры о том, чтобы украинцы и крымцы освободили пленных татар и украинцев соответственно. В апреле 1656 г. украинцы уведомили перекопского бея Периш-агу о своем посольстве в Крым. Хан Мехмед-Гирей в письме Яну Казимиру просил не подписывать мира с русскими и советовал подписать договор со шведами. После же заключения русскими и поляками Виленского перемирия хан просил Яна-Казимира отречься от союза с Москвой [Kolodzejczyk, с. 964-973], [Перналь, с. 129-184], [Чухліб, 2010, c. 196-199], [Чухліб, 2017, с. 43-46].

В связи с этим необходимо в общих чертах рассказать о кампании 1654-1655 гг. на украинских землях. В конце 1654 г. крымцы выступили в войне на стороне поляков. В Летописце Дворецких сказано, что в 1655 г. около Дрыжиполя Хмельницкий многих поляков уничтожил, 
да и татары понесли потери [Мицик, 1984]. Ф. Софонович сообщал, что в 1654 г. осенью пришли поляки под Брацлав, и к ним там присоединились и татары. Сообщалось, что не татары, а поляки разбили Томиленка, а других полковников вынудили отступить в Умань. Под 1655 г. сообщалось, что поляки и татары осадили Умань и на протяжении трех дней усиленно штурмовали. Хмельницкий и Шереметьев двинулись на выручку городу, однако были окружены между Ахматовым и Ставыщами на Дрыжиполи. Указано, что казаки и русские мужественно давали отпор полякам и татарам. Отмечалось, что после этого Хмельницкий с Бутурлиным двинулись ко Львову и взяли контрибуцию с этого города, но когда казаки возвращались, то их татары окружили под Озерной. Много казаков попало в плен к татарам, но русские и украинцы в целом смогли отразить татар, а русских много погибло не в битве, а при отступлении зимой [Софонович].

В Черниговской летописи указывалось, что много татар было под украинскими городами. Сообщалось, что хан пришел под Смелу, Волховец и Звенигородку. Отмечалось, что хан разозлился на Хмельницкого за то, что тот принял русское подданство, и многих казаков, которые шли из-под Львова, откуда повернули после общей с русскими осады этого города, уничтожал и самого Хмельницкого под Озерной чуть не схватил. Однако казацкому гетману удалось, используя дипломатические приемы, договориться с крымским ханом [Черниговская летопись].

В Лызогубовской летописи отмечалось, что в 1654 г. Ян Казимир послал Исламу-Гирею III 100 тыс. злотых, однако эти деньги уже принял следующий хан, который, приняв эти деньги, пришел на Украину и опустошил многие местности. Под 1655 г. сообщалось, что поляки и татары под Уманью осадили И. Богуна, а потом между Ставыщами и Ахматовым окружили и самого Хмельницкого, однако казаки отразили их нападения. После осады Львова казаки отдельными отрядами шли назад, и их уничтожали татары, а под Озерной крепко потеснили Хмельницкого, однако тот сумел дать отпор, а после этого договорился с ханом, который отдал в заложники нескольких членов династии Гиреев. Казаческий гетман встретился с крымским ханом и выслушал от него угрозы, а также укор за то, что принял протекцию не турецкого султана, а русского царя. Сам же хан желал отвоевать у русских Астрахань. Хмельницкий же делал упор на то, что татары вынесли немалую пользу от совместной войны с казаками против поляков и брали ясырь. Также он укорял за то, что Ислам-Гирей III бежал с поля боя при Берестечке [Лизогубівський літопис].

В летописи Самовидца указывалось, что зимой 1654-1655 г. польский король отправил послов к хану в Крым и что тот прибыл с большими силами. Сообщалось, что на Дрыжиполи между Слободищами и Уманью украинцы были окружены и что в битве полегло множество поляков, а также много татар. О битве при Озерной летописец молчал [Літопис Самовидця].

С. Вэлычко сообщал, что, не дождавшись исполнения королем условий Жванецкого мира, хан отправил против поляков свое войско. Крымцы, для того чтобы взять ясырь, рассеялись по Волыни, Полесью, а также достигли польских земель у Замосця и Люблина. Сообщалось, что Сапеги, направленные против татар, разбили ряд чамбулов. Потом, проходя по землям от Украины назад до Крыма, крымцы ограбили и их. Отмечалось, что 15 тыс. татар, которые действовали в Великом Княжестве Литовском, должны были возвратиться через Киевщину. Около Белгородки и Межигорья их встретили казаки и перебили. Были освобождены люди, взятые в ясырь. 1,5 тыс. татар и 11 мирз были взяты в плен, иная добыча распределена между казаками. Сообщалось, что после прибытия из Крыма посла Яскольского при польском дворе появился татарский посол Сулейман-ага. Он требовал дань в 600 тыс. и присягу, согласно которой поляки не будут воевать против Крымского ханства. Король пообещал исполнить эти условия, а хан в свою очередь пообещал отправить против казаков значительное войско. Поляки же обещали, что с ними против казаков выступят трансильванский князь, господари Валахии и Молдавии. К власти в Крыму через некоторое время после смерти Ислама-Гирея пришел новый хан, который через калгу подтвердил союз с поляками. Хмельницкий пытался дипломатическим путем расколоть этот союз, отправив посланца к хану, однако тот после совета с мирзами был исполнен решимости придерживаться мира с поляками. Под 1655 г. сообщалось, что хан поставил перед Хмельницким ультиматум, требуя, чтобы он ограничил казаков 10 тыс. реестра, позволил шляхте вернуться на свои земли, отказался от союза с русскими и признал своим государем только короля Речи Посполитой. На это гетман 
ответил отказом, и тогда татары под Уманью соединились с поляками. Во главе татар стоял сын умершего хана. Его отряды брали ясырь на территории до Днепра, а численность всего войска была в 40 тыс. Б. Хмельницкий с 25 тыс. двинулся под Ахматов, где в четырех верстах в чистом поле был окружен поляками и татарами. Счастливый исход битвы для казаков предопределил удар И. Богуна в тыл полякам. Одновременно с ним против поляков и татар выступил и Хмельницкий, в результате чего поляки и татары были вынуждены отступить. Украинцам помогало и русское войско. При этом в битве на Дрыжиполи поляки понесли основной урон, а татары отступили с ясырем. Сначала одна их часть покинула поле боя, а потом и вторая. При этом польский гетман укорял мирз в том, что из-за них была проиграна битва, они разгневались и оставили поле боя. Часть татар, отправленных ханом брать ясырь в Полесье, еще не вернулась назад. Этим воспользовался Хмельницкий, отправив против них 10 тыс. казаков во главе с Богуном. Тот разбил отдельные татарские отряды под Чудновом, Котэльным, Кодно, Кормыном, которые возвращались к кошу около Умани. Погибло 8 тыс. татар, а 2 тыс. 50 человек было взято в плен. 500 из пленных татар Хмельницкий отправил как дар русскому царю. Только те татары, которые были у Полонного, смогли возвратиться целыми и с ясырем домой. Те татары, которые не были подарены русским, выкупили себя из плена [Величко].

Г. Грабянка указывал, что в 1653 г. татары, возвращаясь назад через украинские земли, многих забрали в плен. Потом поляки пришли к союзу с крымцами, король обещал хану помочь отвоевать Астрахань. В обмен на это хан обещал Польше покорить Украину. При таких условиях украинцы перешли в подданство русским. Казацкий летописец пересказывал слух, что хана отравила рабыня из Украины, которая подавала ему вино. Сообщалось, что новый хан разбил наказного гетмана Томиленка и под Уманью осадил И. Богуна зимой 1654-1655 г. Б. Хмельницкий шел на помощь, но его под Ставыщами и Ахматовым окружили поляки и татары. Сообщалось, что сражались главным образом казаки с поляками. На второй день поляки и татары снова атаковали казаков, однако казаки подкупили татар, и поляки снова сражались с казаками, пока из-под Умани не пришел Богун. Татары взяли ясырь и просили поляков идти к Днепру, но те, понеся потери, не смогли это сделать. Когда казаки возвращались из по- хода во Львов, их окружили около Озерной татары, но не смогли им нанести поражения, и дело закончилось переговорами. Хан укорял гетмана, что он забыл то добро, которое ему сделали татары, когда он воевал против поляков, которых боялся даже австрийский кайзер. Казацкий гетман же указывал, что в начале восстания хан отправил только одного Тугайбея. Указывал, что под Корсунем и Пылявцами казаки добыли победу, что под Пылявцами было только 4 тыс. Карач-бея. Гетман обвинял хана, что воля крымского хана не позволила ему разбить поляков под Зборовым и Жванцом, что только по доброй воле казацкой судна хана могут плавать на Черном море и по рекам, что Ислам-Кермен благодаря тому только и цел, что крымцы присоединились к полякам, стоило только им пообещать, что при помощи короля они отвоюют Казань и Астрахань. В ответ хан ответил, что, мол, Исламу-Гирею Хмельницкий боялся такие слова говорить. Однако вряд ли такие речи говорили сами гетман и хан, иначе бы они не нашли компромисса. Эти слова им приписал казацкий летописец спустя несколько десятков лет, не скрывавший своей антитатарской позиции [Літопис гадяцького...]. В украинской летописи «О начале мира, особо о Польше и Малой Росии» указано, что в 1655 г. татары, напав на Хмельницкого, под Озерной почти разбили [Мицик, 2015, с. 238].

Несколько отличается описание событий у поляков. И. Ерлич под 29 января 1655 г. сообщал, что между Пятигорами и Ахматовым татары под руководством калги и поляки встретились с казацким и русским войском численностью более 100 тыс. Силы татар же оценивались в 40 тыс. В ходе битвы поляки побеждали, а русские хотели перебежать к полякам. И. Выговский начал отступать к Ахматову, и его отряд преследовали отряд Лянцкоронского и часть татар. Видя неблагополучное течение битвы, Хмельницкий подкупил часть мирз, и те покинули поле боля. Сообщалось, что русские и казаки после этого пришли ко Львову, и, чтобы их отразить, поляки призвали на помощь татар. Крымцы прошли около Галича, Перемышля, Ярослава, и местное население пострадало от них. Отмечалось, что Хмельницкий был окружен войсками хана под Озерным около Зборова и Тернополя. В битве погиб ряд русских бояр. Потом хан двинулся к Днестру и Каменцу. Где раньше было 40 тыс. населения, там после крымцев и 8 тыс. не насчитывалось [Erlicz, c. 167-168, 173-174, 176-178]. 
В «Краткой истории о бунте Хмельницкого» было указано, что в 1655 г. поляки с татарами двинулись против казаков. Отмечалось, что татары в Запорожье ходили за ясырем. Coобщалось, что под Ахматовым поляки разгромили Хмельницкого, если бы в тыл не ударил в И. Богун. Отмечалось, что хотя крымцы и окружили казаков, но более думали о подарках и добыче, чем об успехе совместного предприятия. Когда татары брали ясырь, Хмельницкий смог уйти к Белой Церкви [Краткая история о бунтах Хмельницкого...], [Historya o buntach Chmelnickiego].

В. Коховский отмечал, что в 1654 г. хан в знак доброй воли освободил двести знатных поляков, находящихся в неволе у татар. Хан направил на помощь полякам 30 тыс. воинов, и эти силы 28 октября соединились с поляками. С крымцами было 20 тыс. конницы и 8 тыс. пехоты поляков. Поляки взяли Мурафу и Краснэ, Чарнецкий планировал взять Киев. Крымцы с поляками объединились у Брацлава. Крымцы возглавлялись мирзами Ахметом и Камамбетом. Вместе они взяли Дембовку, но Умань, которую укрепил И. Богун, не смогли взять. Хмельницкий собирался с русскими на помощь осажденным, но поляки и татары под Ахматовым их окружили. В. Коховский сильно преувеличивал силы неприятелей, указывая, что только русских было 80 тыс., а конных калмыков 20 тыс. Поляки обстреливали лагерь казаков и русских из пушек. Лянцкоронский хотел взять русско-украинский лагерь, не теряя сил конницы. Ночью татары отступили от лагеря, поляки спрашивали, почему те отошли, на что получили ответ, что не привыкли воевать ночью и что стоят морозы. Польская пехота страдала не меньше, и много солдат умерло из-за морозов. Потом, по сведениям хрониста, стало известно, что Камамбет был подкуплен Хмельницким, а потом к калге от казаков были послы с подарками. Поляки были вынуждены отступать, а крымцы отошли в свои владения и около Саврани собрались с русскими и украинскими людьми, забранными в ясырь. Хан обещал Яну-Казимиру 100 тыс. войска. На помощь королю против шведов пришло 20 тыс. татар Зихмирзы [Kochowski, с. 187-199, 201-202, 212, 223].

В «Войне Домовой» Самуэля Твардовского сказано, что умер хан и что в Крым прибыл новый хан. Калга и брат хана вместе с новым правителем посоветовались и отправили к королю послов с предложением дружбы. Письмо было послано через Челеби. Хан обещал разорвать союз с казаками и быть союзником против всех врагов. Возвращаясь назад, Челеби встретил украинского посланика, который обещал большие упоминки. Крымский правитель вел переговоры с обеими сторонами. Крымцы выступили против казаков, когда поляки вторглись в Брацлавскую землю. Мелин-Гирей (МенглиГирей) привел 40 тыс. войска. Отмечалось, что татары ограбили украинские села, а МехмедГирей подошел через некоторое время с большой ордой. Самуэль Твардовский с сожалением говорил, что нет толку от дружбы с поганами, дружбу эту оплатили жизнью христиан, и зря с татарами заключили союз и оплатили союз ясырем из христиан. Выражалось сожаление, что не уважали Зборовского мира и греческой веры [Мицик, 2015, с. 230-234], [Twardowski].

В «Рифмованной хронике» Самуэль Грондский упоминал, что русских и украинцев было 100 тыс., а татар несколько десятков тысяч. Татары дали знать польскому гетману, что на него идет огромное войско. В Ахматове оно было окружено. Отмечалось, что татары с криками «Аллах, аллах» крепко ударили по русским и вместе с поляками чуть не взяли русскоукраинский лагерь под Дрижиполем. Хмельницкий переманил на свою сторону нуреддина, обещав ему золото и серебро за то, что тот не будет нападать на лагерь украинцев. Поляки были обижены на нуреддина за его поведение. Тогда татары начали брать села и города, которые были населены поляками. Поляки же боялись, так как думали, что на них нападает многочисленная татарская орда. Чтобы обеспечить союз с татарами, поляки обеспечивали вольный путь на Украину и не мешали брать ясырь. Татары нанесли много убытков русским и украинцам. Много людей стало невольниками. В 1657 г. Хмельницкий хотел привести в Польшу хана с его ордой. В 1659 г. Е. Любомирский вместе с татарами вторгся в Венгрию. Еще ранее, в 1658 г., поляки воевали в Трансильвании и только в 1660 г. вывели свои войска из страны. Под 1658 г. сообщалось, что хан разбил Яноша Кеменя над рекой Стрепой у Зарваницы. Многие венгры попали в плен. Татар польский хронист сравнивал с волками и описывал их неприхотливый кочевнический быт. Отмечалось, что татары готовы напасть на поляков, немцев, русских, украинцев, венгров. С. Грондский в «Хронике польско-казацкой войны» указывал, что татарский хан пришел под Тернополь. Отмечалось, что крымцы уничтожили 
многих русских, которые шли отдельно от украинцев. Потом хан ожидал поляков на Покутье [Мицик, 2015, с. 259-263, 268-281, 298299]. Молдавский хронист Мирон Костин сообщал, что казаки бросили татар и приняли московское подданство. Зимой 1654-1655 г. татары вместе с поляками нанесли много убытков казацкой земле. Они осадили украинцев и русских в одной местности [Miron Costin], [Мицик, 2015, с. 308-309].

С. Ревера Потоцкий указывал, что татары не прибыли своевременно. Османский султан Мехмед IV писал, что зимой 1654-1655 г., изменив присяге, воевал вместе с молдаванами и венграми против украинцев. В этой ситуации Хмельницкий просил о турецком протекторате над Гетманщиной. Турецкий султан предлагал украинцам наладить отношения с теперешним ханом (Мехмедом-Гиреем IV). 2 ноября были выдвинуты условия крымско-украинского примирения: казакам приказывалось покинуть русских и признать своим законным правителем Яна Казимира. Реестровцев должно быть 6 тыс., да и те должны быть перемешаны с польскими и венгерскими пехотинцами, чтобы никаких дипломатических действий украинцы не предпринимали без согласия короля и чтобы шли громить Карла Х Густава. Естественно, на такие условия украинцы не могли согласиться. 27 ноября в письме к С. Потоцкому МехмедГирей отмечал, что он часть Украины опустошил, но вынужден был остановиться под Соленым городком для сражения против украинцев и русских. Хан обещал польскому гетману усеять земли от Каменки до Зборова телами казаков, которые возвращались из-под Львова. Также он обещал расправиться со шведами. Через два дня он написал коронному маршалку Е. Любомирскому: он сообщал, что крымцы находятся на Покутье и ждут, пока к ним присоединятся поляки. Посол Речи Посполитой в Крыму М. Яскульский сообщал, что хан пришел к Тернополю и собрал мурз и беев на совет. После него отдельные отряды пришли под Тернополь, Микулинцы, Теребовлю и Стрыжив. Когда украинцы и русские переправлялись у Озерной, на них напали ногайцы из крымского войска. Они убили сразу же несколько сот русских. Войско украинцев и русских было осаждено в Диброви. Во время битвы Ян Казимир прислал хану письмо, в котором предлагалось, чтобы Хмельницкий был образумлен. Когда татары начали давить украинские войска, то встретили ожесточенный огонь из мушкетов и пушек. Камамбет был ранен, и тогда Субханкули-ага, Аз-Мирза и Карач-бей начали переговоры, укоряя Хмельницкого за то, что тот изменил присяге, данной Тугай-бею. Украинцы отвечали, что вошли в союз с русскими из-за того, что хан заключил союз с поляками. Крымцы же говорили, что много раз присылали посольства и проявляли дружелюбие, только бы украинцы покинули русских. Казацкие послы говорили, что готовы жить в мире с поляками и крымцами. Однако они наотрез отказались от выполнения ультимативного требования по выдаче русских крымцам, говоря, что это большой грех. После этого возобновились поединки между украинцами и крымцами. Немного погодя стычки прекратились. Хан собрал совет и решил примириться с Хмельницким и убрать требование выдачи русских, лишь бы заключить мир и союз с казаками. Хан подарил Бутурлину коня. Единственным условием было стать подданными Яна-Казимира [Мицик, 2015, c. 14, 25-26, 30-32, 34-35].

20 апреля 1656 г. И. Выговский отправил письмо перекопскому Пырыш-аге. Он просил, чтобы ага посоветовал хану сохранять дружбу с казаками. Предлагалось вместе сражаться против общих неприятелей. Казимир Стаховский, захваченный русскими, в документе от 25 февраля 1657 г. сообщал, что Б. Хмельницкий готов снова стать союзником татар, стать союзником шведов, венгров и поляков против русских. Из немецкого летучего листка известно, что в войске Дьёрдя Ракоци II находятся сеймены (сеймены-татары), казаки, валахи, молдаване, венгры, опришки. В конфессате пленных венгров, шведов и казаков после 8 мая 1657 г. указывалось, что шведы отправили послов в разные страны: в частности, в Крым прибыл королевский камергер Лелизор. Отмечалось, что войска Ракоци насчитывают 37 тыс., из которых 7 тыс. немцы, казаки, сеймены. В документе от 3 июня 1654 г. Мартин Пушкар и Яков Барабаш говорили, что стоят в поле, оберегая страну от набегов татар. Они просили И. Выговского дать знак хану, чтобы крымцы отступили от земель украинцев. Иван Желябужский писал Дьёрдю Ракоци, что Онтон полковник (так он называл Антона Ждановича) готов выступить вместе против турок и татар к Каменцу-Подольскому. Позже он говорил, что они не смогут присоединиться к венграм у КаменцаПодольского, поскольку с ними воюют русские. Позже крымский хан пришел со всем войском в город. Отмечалось, что войско украин- 
цев было рассеяно, а крымцы потом разбили войска Дьёрдя Ракоци и после победы ушли с казной трансильванского князя и ясырем в Крым. Также они воевали в Молдове. Крымцы звали поляков воевать против украинцев. Однако те отказались от похода на казаков. Татары обиделись на поляков также за то, что те не выдали Дьёрдя Ракоци. Польский король заплатил некоторую сумму крымцам за помощь. Евстафий Выговский в письме к Павлу Тетере от 11 августа 1657 г. указывал, что казаки страшно опустошили Крымское ханство. В письме неизвестного неизвестному в сентябре 1657 г. указывалось, что жители пинчане помогали казакам громить татар. Силистрийский паша Чауш писал Богдану Хмельницкому, что между казаками и татарами произошла ссора. В новостях из Варшавы говорилось, что в декабре в город прибыл крымский посол, который предлагал выступить против казаков, поскольку настало хорошее время для их разгрома [Мицик, 2015, c. $53,71-72,78,95-96,102,104-105,109-110$, 113-116, 123, 131-132].

Украинский посол в Крыму Михаил Богаченко в письме от 26 октября 1654 г. говорил, что его в посольство отправил переяславский полковник из Каменки вместе Камамбетмирзой. Он прибыл в улус Келимбет. Тогда у татар было неспокойно. Блюдас-салтан, СефанГази и Сефер-Гази-ага прислали к посольству Камамбет-мирзу, чтобы войском устрашить мятежных султанов. Когда в Джан-Кермене услышали о посольстве запорожских казаков, то Корага-султан и Сефер-Гази помирились с беями. Нураддин-султан и Сафан-Гази-ага стояли у Перекопа. Камамбет же их боялся и обошел Перекоп через лиманы. Посольство должно было передать документы хану и беям, что Богаченко и сделал. Посол был отослан в Старый Крым. Хорунжий Корицкий прибыл к Нураддин-султану и Сафан-Гази-мирзе. Там он узнал, что татары решили побрататься с поляками и огнем и мечом разорить всю Украину. Камамбет-мирза присягнул польскому послу, что он поможет королю и возьмет в плен Хмельницкого. Украинцев корили за то, что они заключили союз с Москвой. Войско татар собралось у Перекопа и простояло там несколько недель. Киевский писарь сообщал сведения от невольника-украинца в Крыму. Все лето поляки и король присылали послов к Исламу-Гирею и к беям. Хан же отправлял мирз к королю. Сам король и сенат присягнули татарам. Украинским послам татары сказали, чтобы они оставили Москву, и говорили, что имеют приказ из Стамбула воевать вместе с поляками. Карач-бей через три дня после этого призвал к себе казацких послов. Собрав абызов, кади, мирз, он требовал от украинцев следующее: оставить Москву, а если этого не будет сделано, то силами турок, венгров, валахов и поляков Украина будет разорена. В то время пришел крымский посол на Украине Байтемир-ага, который говорил, что гетман просил присягнуть татар, и тогда он разорвет отношения с Москвой. Потом призвал украинцев СеферГази-ага и требовал отстать от Москвы и вернуться под польскую власть. Карач-бей говорил, что все казаки погибнут, если не оставят Москву. Он разобьет сначала казаков, а потом Москву. Потом послы побывали у хана, который говорил, что хочет жить с гетманом, как прежний хан (Ислам-Гирей). Хан же отправил Кая-бея к ногайским мирзам, в частности в Буджак. Калга-султан тоже должен был переправиться на правобережье Днепра. Польского посла после украинских послов хан отпустил вместе с сыном Тугай-бея Али-беем. Хорунжего Яскульского оставили в Крыму. В посольство к туркам отправили Бекгановского и Белецкого. Тогда султан обещал отправить стотысячное войско на Москву. Сафар Кази-ага Левер, толмач Ивана Выговского, провожал из Крыма посольство во главе с Михайлом Богаченком [Чухліб, 2017, с. 203-206].

Литовский подстольный Игнаций Сципион сообщал, что в 1655 г. крымский хан вынудил Хмельницкого признать своим королем Яна Казимира. В автобиографии Богуслава Радзивилла указывалось, что Богуслав был взят в плен Субханом-гази в битве под Простками в 1656 г., но был освобожден паном Войновичем. В мемуарах А. Радзивилла под 1655 г. упоминалось, что крымский хан привел Хмельницкого к подданству королю. Николай Емелевский сообщал, что под Умань пришел брат хана с 20 тыс. войска и вместе с поляками там потерял две недели, штурмуя крепость. Под Ахматовым 60 тыс. русских и украинцев были окружены татарами и поляками. Отмечалось, что татары, которые были давними побратимами казаков, во время штурма два раза неожиданно отходили назад. В Приднестровье пришел калга с 60 тыс. войска и встретился с крымцами в Бершади. Отмечалось, что татары и от поляков, и от украинцев получили много золота и других богатств. С. Лянцкоронский указывал, что в Ободивке польный гетман встретился с ханом. В 
свите хана были Камамбет и Ах (Ак)-Мурза. В письме неизвестного к неизвестному от 4 февраля отмечалось, что враг слал к Камамбетмурзе дары, чтобы татары отделились от поляков. Татары устранились от битвы. Русские послы в Крыму доносили, что там находился нуреддин, а калга воевал на Украине, и татары привели оттуда множество пленных. В письме от 23 февраля 1655 г. сказано, что С. Лянцкоронский отдал в ясырь татарам 10 тыс. из Кисовоничинец. Также отдали татарам в ясырь жителей Махнивки, Яланивки, Сульпиховой, Скародной, Кочубиевки, Сухой Дибровы. В письме Яну-Казимиру от 27 февраля крымский хан писал, что отправил послов к казакам и что настаивал, чтобы те отошли от русских. Также он хотел, чтобы гетман пошел вместе с крымцами против врагов хана. В письме от Сефер-Гази от этого числа сказано, что он отправил трех послов к казакам и предложил, чтобы они отошли от русских. В июне 1655 г. в письме С. Реверы Потоцкого сказано про приход калги после отъезда Мелима-султана (Менгли-Гирея). Король инструктировал М. Яскульского, что необходимо добиться аудиенции у Менгли-Гиреясултана и напомнить ему о польско-крымском союзе. В немецком летучем листке 1656 г. говорилось о письмах хана к польскому королю. Летом 1655 г. по инициативе хана поляки начали переговоры с украинским гетманом. Мехмед-Гирей в 1656 г. писал, что Хмельницкий отправил посла к турецкому султану. В инструкции польскому послу в Крым осенью 1655 г. Ромашкевичу было сказано, чтобы хан повлиял на Хмельницкого и чтобы тот заключил мир. В ноябре 1655 г. нуреддин Адиль-Гирей отправил в Каменец-Подольский своего посла Камамбета, чтобы узнать, где король и где татарам объединиться с поляками. Находясь под Галичем, в этом месяце хан писал королю, что он воевал с русскими и украинцами под Соленым городком и опустошил значительную часть Украины. Он обещал усеять трупами пространство от Каменки до Зборова. Немного погодя сообщали, что татары громили казаков под Озерной и что сам Хмельницкий с полковниками просил хана принять его в вассалы польского короля. В «Письме о прусских делах» приведены слова шведов о том, что казаки и татары - польские союзники. В письме виленского воеводы из Кенигсберга от 4 января говорилось, что казаки и татары должны соединиться с войсками ЯнаКазимира. В январе 1656 г. киевский воевода писал королю, что на Брацлавщине было 30 тыс. Менгли-Гирея. В войске были ногайские мурзы Келимбет и Шах. В инструкции Яну Шумовскому, послу от короля к хану, предписывалось, чтобы запорожцев сделать верными королю и чтобы Хмельницкий покинул русских. Также требовалось добиться, чтобы 10 тыс. татар и 10 тыс. украинцев пришли на подмогу полякам. В мае 1656 г. Ян-Казимир просил помощи у хана для того, чтоб одолеть Дьёрдя Ракоци. В летучем немецком листке от апреля 1656 г. говорилось о письмах хана к польскому королю, переговорах с казаками, о татарах и помощи с их стороны. В мае-сентябре 1656 г. говорилось, что в мае запорожцы напали на ураловы улусы ногайцев. В то же время прибыли послы от Хмельницкого, которые добивались дружбы крымцев. Также прибывали украинские послы в августе и сентябре 1656 г. В июле 1656 г. турки и татары выступили против Дьёрдя Ракоци. В августе 1656 г. хан отправил 20 тыс. буджакцев против шведов. По данным немецкого летучего листка после 11 октября 1656 г. говорилось о победе литовцев и татар над брандербуржцами и шведами под Простками. Это же событие зафиксировано в еще одном летучем немецком листке от того же месяца [Мицик, 2015, с. 214, 221, 239-248, 315, 317-335].

В письме Ислама-Гирея от второй половины января 1654 г. хан обвинял гетмана в том, что он изменил присяге и что не имеет права без позволения хана заключать договоры не только с иноземными монархами, но и со своим монархом - польским королем. Он требовал, чтобы гетман отрекся от присяги Москве. Он призывал вместе воевать против Москвы. Гетман ответил: в письме от 16 апреля 1654 г. он говорил, что на переговорах под Каменцем татары не помогали казакам. Татары разграбили часть владений казаков, когда возвращались из похода, и это вынудило Войско Запорожское сомневаться. Кроме того, были нарекания от гетмана, что он оказался в опале у хана. Также отмечалось, что Потоцкий вместо мира воевал против казаков и ему помогал опустошать поселения казаков Глигорус Гурмас. Они вторглись в украинские земли по самую Умань, но казаки вынудили поляков отойти. Гетман говорил, что союз с Москвой был заключен согласно совету крымского хана, который ранее говорил, что поляки набирают людей из разных краев, чтобы погубить казаков. Касательно Смоленска и других городов, что Москва отобрала у короля, гетман говорил, что не знает об 
этом. Касательно того, что казаки задержали татар, сказано, что их отпустили. Более детально об этом сообщить был должен посол украинцев в Крыму Семен Савич. Говорилось, что во время боев под Уманью в плен попал ксендз Потоцкого, который выставлял дело так, что Потоцкий не хотел воевать, но его заставил король, который отправил на войну королевича Карла. Карл должен был получить помощь татар. Эти данные были подтверждены письмами из Литвы, которые были при убитом поляке. Гетман просил хана со всеми агами и беями выступить против общих врагов. В письме Мехмед-Гирея IV Богдану Хмельницкому сказано, что к украинцам пришел Токтамыш-ага. Гетман высказывал пожелание, чтобы новый хан вел себя по отношению к казакам, как ИсламГирей. Хан в своем письме, отправленном с Токтамышем, угрожал, что если казаки не отступят от Москвы, то он натравит на них венгров, мультян (валахов) и валахов (молдаван). Гетман говорил, что не преступал клятву, а наоборот, король Владислав был наказан за это. Богдан говорил, что не боится тех, кого на него хочет наслать хан, и надеется на Бога, а вовсе не на Москву. Гетман обещал дружить с ханом и просил прислать какого-то вельможу для нового договора. Более детально хану должен был изложить Токтамыш-ага. 2 ноября 1655 г. Войско Запорожское заключило новый договор с Крымским ханством. Гетман признавал своим господином Яна Казимира, обещал отступить от Москвы, реестр мог быть более 6 тыс., обещал не заключать договоров с иноземными странами в обход поляков. Богдан обязывался воевать против шведов. Из письма Богдана Хмельницкого от 31 января 1656 г. становится ясно, что гетман всего этого избежал, ссылаясь на трудные обстоятельства [Чухліб, 2017, с. 199-203, 206-210].

Самуил Пашковский в письме к Яну Владиславу Радзивиллу от 9 января 1657 г. писал, что русские вместе с украинцами и татарами погубили всю Литву. В письме из Ченстоховы от 17 марта говорилось о намерении татар снова напасть на Трансильванию. В мае 1657 г. сказано, что татары нанесли много убытков украинским землям у Чечельника. В апреле 1657 г. хан, калга, визирь отправляли письма в Речь Посполитую. Субхан-кули-ага в одном документе от апреля 1657 г. был назван правителем Буджака. В новостях от 30 мая сообщалось, что 3 тыс. казаков перегодили путь татарам в Молдову и Украину. Субхан-Гази-ага писал, что украин- цы, венгры, молдаване, валахи пошли войной на польского короля. Он заявлял о готовности вторгнуться во владения венгров (Трансильванию). В инструкции Ромашкевичу от мая 1657 г. указывалось, что хан воюет против русских. В инструкции С. Беневскому, послу от Речи Посполитой к Б. Хмельницкому, указывалось, что нужно довести до ведома гетмана о походе турок и татар в Трансильванию. В английском летучем листке после 15 августа говорилось, что 15 августа татары разбили трансильванцев под Вишневчеком. В письме Николая Салги к Анджею Конецпольскому от лета 1657 г. говорилось о том, что татары уничтожили 800 рейтар курфюрста. В анонимном письме от 14 сентября 1657 г. указывалось, что татары опустошали украинские города на границах с Русским государством. В письме Яна Казимира русскому царю Алексею Романову от 17 октября 1657 г. говорилось о том, что татары и турки воюют против Дьёрдя Ракоци. В октябре 1657 г. подьячий Артемий Федоров сообщал о нападении казаков на Крым и ногайские улусы. Запорожцы напали на Крым и ногайцев в числе 7 тыс. В ходе похода запорожцы потеряли сотню воинов. Они убили 15 тыс. татар, а 5 тыс. татар привели в ясырь в Запорожье. С татарским войском они сражались у Перекопа [Мицик, 2015, c. 337, 340-343, 345-347, 352-354, 356-358].

События на Украине интересовали и французов, например, Г. де Тарда и Ж.-Б. Шерера. Последний отмечал, что в 1654 г. польский король заплатил 100 тыс. золотых крымскому хану Селиму-Гирею, чтобы тот напал на казаков. Но он умер, и власть перешла к его брату Менгли-Гирею, который вторгся на Украину и разбил отряд Томиленка. Под 1655 г. сообщалось, что татары с поляками атаковали пять полковников под Уманью. Те смогли прорваться из окружения. Потом поляки и татары напали на Хмельницкого под Дрыжиполем. Однако заслуга в победе приписана одним только украинцам и указано, что украинцы с боями пробились к Белой Церкви. Потом был поход вместе с русскими, когда их союзное войско дошло до Львова, Люблина и Замосця. Возвращаясь из похода, Хмельницкий столкнулся с татарами у Озерной. Однако хан не смог разгромить казаков и пошел с ними на переговоры, предварительно отправив 12 заложников к украинцам. При переговорах казацкий гетман обвинял крымского хана, что он изменял договорам с казаками, служил тому, кто больше заплатит, сделал много убытков казакам, что стоило 
только пообещать хану Астрахань, так тот был готов уничтожить всю Малороссию (так в хронике). Крымский хан разозлился на это и обещал, что погубит как самого гетмана, так и его войско. В целом текст Ж.-Б. Шерера был близок к летописи Г. Грабянки [Gaspard de Tende 1697], [Шерер 1994].

Сведения этого французского историка имели ряд неточностей, поскольку татарами правили ханы с совсем другими именами. Казацкие летописи традиционно приуменьшают масштабы потерь казаков и роль крымцев в конфликте. Польские же хронисты существенно преувеличивают количество русских и украинцев в битве под Ахматовым.

Турок Мустафа Наима сообщал, что ляхи (поляки) отправили письмо к ханскому визирю Сефер-Гази-аге, прося его посредничества в деле заключения мира. Он посоветовался с ханом и его приближенными. Указывалось, что поляки вымотаны семядесятидневной осадой, а Подолье опустошено. Говорилось, что власть в ляшском крае принадлежит беям и что нужно взять в аманаты по два сына из родов наизнатнейших беев и требовать дани с них. Поляки же были готовы пойти на выполнение любых условий татар. Ляшские командующие выехали из лагеря и пришли к крепости Каманиче. Туда же прибыл Сефер-Гази-ага, Катлазиюш и бей Ширинов, а также десять аг. Татары выдвинули требование давать дань хазину, отправить в аманаты сыновей двух наивысших беев, не делать вреда казакам. Также требовали, чтобы поляки отдали население сел и городков края на разграбление, иначе 100 тыс. татар и ногайцев вместе с 80 тыс. казаков снова будут воевать против Польши. Некоторые из татар были против мира с поляками. Это были Кайтас-ага и Кан-Мехмед. Они требовали свернуть переговоры и вернуть Хани-агу, муллу, отданного полякам в заложники. Поляки, однако, пошли на все условия татар, но говорили, что плохо, если казаки будут грабить села и городки. Поляки отправили в аманаты по одному сыну военачальника и какого-то воеводы. 15 декабря 1653 г. был заключен мир. Татарские и казаческие послы вернулись в Вислатен (Гусятин). Татары разорили местности у города Дубно и КартКонстантин (Староконстантинов). Сын Сефераги взял Карт-Константин. Чамбулы татар грабили поселения на Черном шляху. После того как они набрали ясырь, весной 1654 г. прибыл посол от поляков в богатой одежде и на роскошном коне, но с никчемными дарами. В июле
1654 г. умер хан Ислам-Гирей III. Тогда казаки вышли в Черное море и опустошили берега Варны и Эрегли. Кроме того, они напали на Балчик. Сийавуш-паша из Силистрии смог взять в плен экипаж одной чайки. В конце августа Мехмед-Гирей IV отбыл из Турции в Крым. После прибытия он в 1655 г. направил войска в страну казаков, это была месть за набеги на румелийские поселения. Тогда хан без труда взял города, население брал в ясырь и убивал. Далее он двинулся к крепости, которую осаждали казаки и московиты. Тогда осада была снята, и казаки вернулись в свои земли. Когда те отступали в болотистой местности, татары перебили половину из 50 тыс. казаков и 100 тыс. московитов. Московиты, которые уцелели, отошли на три дня пути от места битвы. Там снова на них напали татары, и 5 тыс. из 30 тыс. московитов погибли. Татары после этого вернулись в свои владения и там встретили посольство из 500 московитов с известием, что шведский король овладел страной Ляха. Зимой 1655-1656 г. в январе-феврале было решено вырвать страну ляхов из рук шведов. Естественно, турок завышает и численность войска противника и крымцев [Наїма, с. 164-172].

По дипломатическим документам нам известно, что крымский хан призывал поляков не начинать кампании без крымцев. В декабре 1654 г. крымский посол, посетивший Речь Посполитую, указывал на 50 тыс. татар, готовых выступить в поход. Он говорил, что они готовы выступить в поход на Москву. Крымские мирзы требовали не уничтожать казаков. В январе 1655 г. они выступили походом на Украину. В том же году калмыки вели переговоры о подданстве с русскими и планировали вместе с донцами воевать против крымцев. Действия калмыков ограничивались действиями против касаевцев (остатков Малой Ногайской Орды) в районе Терека. Фактически против альянса крымцев и поляков выступали русские и украинцы. Польский посол Корицкий договорился с буджакскими ногайцами об их походе на Украину. В начале декабря они стояли у Днестра, ожидая, когда замерзнет река и около Рашкова можно будет пройти по льду. А. Раздивилл сообщал, что крымцы с коронным войском соединились еще в декабре 1654 г. 1 января 1655 г. поляки соединились с татарами. Во время зимней кампании Б. Хмельницкий при помощи дипломатии и денег добился того, чтобы крымцы не участвовали в битве при Ахматове 19-22 января 1655 г. Гетман влиял на хана при помо- 
щи мирз, которые были близки покойному Исламу-Гирею III. Нужно отметить, что МехмедГирей IV еще в октябре 1654 г. предлагал Б. Хмельницкому отречься от союза с русскими, чтобы оставаться союзником крымцев. Под Ахматовым активно действовали только поляки, которые взяли в осаду лагерь русских и украинцев. Победа в этой битве была добыта благодаря тому, что И. Богун атаковал противника с тыла и подошел к нему из Умани. Крымцы, не вступив в бой, отступили, ведя с собой ясырь с Киевщины и Брацлавщины. События под Дрыжиполем позволили развернуть общее наступление на запад. Русские войска продвигались на запад территориями Великого Княжества Литовского дойдя до Гродно и Вильнюса, а казаческие отряды вместе со вспомогательными русскими войсками вторглись на коронные земли и через Волынь и Подолье пришли в Галичину. В битве под Городком в сентябреноябре они разбили войска С. Потоцкого, а потом взяли в осаду Львов. Поражения Речи Посполитой стали сигналом для шведов, которые вторглись в Польшу летом 1655 г. [Федорук, 2011, с. 83-86, 91-96], [Літопис гадяцького...], [Величко], [Грушевський], [Софонович], [Podhorodecki, c. 190-194].

В 1655 г. крымский хан Мехмед-Гирей IV отправил в Европу ряд своих посольств. Крымское посольство двинулось в путь в конце декабря - начале 1655 г. Посольство возглавлял Майдан Гази-бек. Посольство добиралось в Австрию через Речь Посполитую, поскольку трансильванский правитель в то время был враждебен к полякам. Нужно отметить, что ЯнКазимир отрядил своих людей сопровождать татар до австрийской границы. В конце февраля 27 числа австрийский император дал аудиенцию крымскому послу. Это событие нашло отображение в английских и немецких газетах. Татарин подарил кайзеру коня, который стоил 1 тыс. дукатов и был удивительно вынослив. 1 марта кайзер дал прощальную аудиенцию крымскому послу и подарил золотую цепь и 1400 дукатов на обратную дорогу. Крымцы сообщали австрийцам про восхождение на престол нового хана Мехмеда-Гирея IV, а также сообщали о дружбе с австрийцами. Предлагалось послать на помощь полякам имперские войска. Голландский резидент в Вене указывал, что хан потребовал от кайзера финансовой или любой другой поддержки Речи Посполитой. Польские же послы говорили, что польское войско в обозримом будущем должно объеди- ниться с татарским и что они вместе вступят в провинции, занятые врагом [Федорук, 2010, с. 45-46].

В том же году прибыло посольство в Данию (в конце декабря 1654 - июле 1655 г.). Самих документов о контактах в Датском королевском архиве не осталось, но их черновики сохранились. Это были ответы на предложения татарской стороны. Посольство крымцев в Данию коррелировало со стремлением Речи Посполитой противопоставить шведам датчан. Из ответа датчан крымцам можно сделать вывод о том, что датскому королю пришло шесть писем от крымского хана, его главной жены, калги ГазиГирея, нуреддина Адиль-Гирея, визиря Сефер Гази-Аги, казначея Джан-мирзы-аги. Хан писал королю, что заключил союз с Яном-Казимиром и что предлагает ему с таким же уважением, как и он, относиться к польскому королю. Ленчицкий воевода Я. Лещинский упоминал о датском шкипере, перевозящем татарского посла. Ответ датского короля крымцам был написан 20 (30) июня 1655 г. Крымский посол должен был прибыть в Данию в середине или во второй половине мая. Вернувшись в свою столицу 8 (18) июня, датский король Фредерик планировал дать аудиенцию крымцам. На этой аудиенции крымский посол сообщал о восхождении на престол Мехмеда-Гирея IV и уверял в дружбе. Хан планировал использовать Данию для участия в антирусской коалиции. Шведский дипломат Магнус Дюрель сообщал, что хан предлагал датчанам напасть на русских морем со стороны Норвегии. 30 июня (10 июля) крымский посол получил ответ, что у Дании нет никаких причин воевать с русскими. Кроме того, крымский посол просил датчан повлиять на Швецию, чтобы она заключила мир с Речью Посполитой. Упоминание об этом есть в письме К. Тышкевича Я. Радзивиллу. Крымский хан требовал от поляков, чтобы они вели переговоры с англичанами и голландцами. 19 мая 1655 г. польское посольство отправилось в Нидерланды, пойдя навстречу просьбам хана. Крымские послы после 20 (30) июня на протяжении еще месяца находились в Копенгагене. Английские газеты сообщали, что татары готовы возвратиться, лишь ожидают воли на это датского короля. В конце июля крымские послы оставили Данию и возвратились через Речь Посполитую, встретившись с Яном-Казимиром [Там же, c. 42-44].

В 1655 г. крымцы отправили в Швецию послов с целым комплексом документов. Перед 
шведами они говорили о дружбе и союзе с Яном Казимиром. В. Беневский сообщал, что посольство в Швецию было инспирировано Яном Казимиром для того, чтобы шведы не задумали воевать с Речью Посполитой. Кроме того, крымцы согласовали свои контакты со скандинавскими странами, правительством Османской Империи. Крымский посол вез с собой письма хана, калги Гази-Гирея, нуреддина Адиль-Гирея, старшей жены хана, визиря Сефер-Гази-аги, а также Тимур-Аги, сына Бахадыр-Гирея Мехмед-Гирея, Али Гази-аги, Абдуллы Керим-Аги, ханского секретаря и Джана мирзы-аги. Письмо хана к шведскому королю было передано через Адильшаха-мирзу, а письмо от жены хана - Али, от нуреддина Муртазу, от секретаря хана - Хассана, от сына Бахадыр-Гирея - Гизеля. Немецкий хронист Иоганн Георг Шледер указывал, что крымское посольство насчитывало 17 человек. Послам были даны инструкции, чтобы использовать шведов против русских. Польский король распорядился, чтобы крымских послов до Гданьска сопровождали пан Юхно, а также бывший польский посол в Швеции Г. Каназилий.

Французский резидент в Швеции сообщал, что крымское посольство прибыло в конце января 1655 г. Шведский дипломат И. Экельбад сообщал, что татары добрались до Стокгольма 9 (19) мая 1655 г., а датские резиденты в Швеции сообщали о посольстве от перекопского (крымского) хана к шведскому королю. Необходимо отметить, что крымцы информировали о восхождении на престол Мехмеда-Гирея IV и поздравляли со вступлением на престол Карла $\mathrm{X}$ Густава. 16 (26) мая 1655 г. крымцы получили аудиенцию у шведского короля. 22 мая (1 июня) переговоры с ними вел шведский канцлер Э. Оксеншерн. Адильшах-мирза убеждал шведов в добрых намерениях хана и в необходимости поддержания мира с Речью Посполитой. В этот же день шведский король ответил крымцам. 24 июня они получили прощальную аудиенцию, а 5 июля крымский посол, получив дары от короля, двинулся в обратный путь. В переписке крымского хана со шведским королем было предложение создать антирусскую лигу из Крымского Ханства, Речи Посполитой и Швеции. В свою очередь, Карл Х Густав писал, что союз с поляками невозможен потому, что в прошлом Сигизмунд III и Владислав IV из династии Ваза неоправданно претендовали на шведский престол. Также отмечалось, что королева Кристина хотела решить противоречия с поляками, но ей это не удалось. Шведский король отмечал, что крымский хан был знаком с польско-шведскими противоречиями. Материалы переписки Сигизмунда III и Владислава IV с крымскими ханами дают нам основание говорить, что крымские ханы были прекрасно осведомлены о притязаниях этих королей и, стараясь заключить союз с Речью Посполитой, включали в титул короля Речи Посполитой титул шведского короля. Шведы просили крымцев не трогать украинских казаков и возобновить с ними союз. В общем крымское посольство 1655 г. было неуспешным [Федорук, 2010]. Украинцы из Гетманщины после заключения союза с русскими в Переяславе старались установить мир с татарским ханом. В февралеапреле 1654 г. оправилось посольство С. Савича в Крым, в августе 1654 г. - посольство П. Тетери [Чухліб, 2010]. В 1657 г. татары возобновили конфронтацию с украинцами. Они заняли много городов на пограничье. Попытка гетмана нейтрализовать крымцев была неудачной. В то время крымцы заключили мир с русским царем. В марте 1657 г. было отправлено посольство Лариона Капусты в Стамбул. В письме янычарскому аге было сказано, что гетман вошел в союз с крымским ханом, однако это было не так. Тем временем Речь Посполитая заручилась союзом с Габсбургами и Данией. Причиной этого было вторжение шведов и трансильванцев, а также намерение русских включить в свое государство западноукраинские земли [Чухліб, 2017, с. 46-52].

Крымские ханы на конфликт с Трансильванией должны были получить санкцию со стороны Османов. И такое позволение было получено Мехмедом-Гиреем IV в 1657 г. В 1655 г. Дьёрдь Ракоци II занимал выжидательную позицию и предлагал полякам свое посредничество в переговорах с казаками. Поражение поляков в битве под Ахматовым обусловило декларацию Дьёрдя Ракоци о своей враждебности в отношении Речи Посполитой. В 1656 г. он вступил в союз со Швецией и Гетманщиной против Речи Посполитой. Участие венгров в войне против Речи Посполитой в начале 1657 г. не было согласовано со Стамбулом, поэтому хан и смог воевать против Трансильвании. Необходимо отметить, что вступление Дании в 1657 г. в войну против Швеции и русско-шведская война вынудили шведов перекинуть свои войска из Польши на другие направления. Войска Дьёрдя Ракоци II, до того бывшие под Краковом и Варшавой, были вынуждены отступать из Польши. Трансиль- 
ванское войско и корпус А. Ждановича были настигнуты С. Чарнецким под Магеровым 11 июля 1657 г. Украинцы бежали не принимая боя, а трансильванцев разбили основные силы поляков, которые напали на венгров тогда, когда они отразили нападение польского авангарда на свой лагерь. После этой победы отряды А. Ждановича оставили трансильванского князя и быстро отступали, а С. Чарнецкий соединился с войсками С. Потоцкого и Е. Любомирского. Кроме того, на соединение с ними шло крымское войско [Санин, 2005, с. 100-125], [Федорук, 2011, с. 90-91], [Літопис гадяцького...], [Величко], [Софонович].

Шведская и трансильванская дипломатия еще в 1655 г. старались разорвать союз Яна Казимира с крымцами, однако нуреддин АдильГирей появился под Галичем, и, благодаря помощи татар, поляки удержали Львов. О столкновении трансильванцев и крымцев сохранились сведения у шотландца Патрика Гордона. Он сообщал, что в 1657 г., когда стало известно о приближении крымцев, казаки рассеялись по Украине, а трансильванский князь капитулировал перед поляками и обязался выплатить им контрибуцию за нанесенные убытки [Гордон].

И. Ерлич сообщал под 1656 г., что татары, опустошившие Подляшье, пришли в Пруссию, взяли в ясырь 100 тыс. немцев и шведов, а шведский полководец отступил. Под 1657 г. сообщалось, что около Черного Острова казаки отделились от трансильванского князя, где его и разбили татары. Из всего войска к Сапеге убежало 400 венгров, а Ракоци и Кемени остались живы [Erlicz, c. 186].

Мустафа Наима, говоря о событиях 16561657 гг., сообщал, что нечестивец Ракоци захотел занять ляшские земли и заключил союз с воеводами Богдана (Молдовы) и Эфляка (Валахии). Он выступил в поход во главе 60 тыс. и был союзником Швеции. Когда он узнал, что против него вышел хан с неисчислимым татарским войском, то разбил лагерь, оградившись рвами. Тогда хан отправил 100 тыс. татар на разграбление Эрделя (Трансильвании), земли Ракоци. Тогда тот решил защищать свою страну и бежал из лагеря, войско же без монарха было разбито татарами. Татары в Эрделе уничтожили много поселений [Наїма, с. 172-174].

Самовидец писал, что на венгров Ракоци в 1657 г. от Подгорья к Меджибожу пришли татары вместе с поляками. Отмечалось, что до того поляки, пребывая в сложном положении, попросили хана прийти на помощь. Через зем- ли Молдавии и регион Подгорья (через Галичину и Малопольшу) крымцы пришли на помощь. Хмельницкий отправил своего сына Юрия на помощь, но тот повернул назад, когда узнал, что Ракоци уже разбит [Літопис Самовидця].

С. Вэлычко сообщал, что в битве под Простками поляки и татары под руководством Гонсевского разбили шведов, взяв в плен трех полководцев, а советник шведского короля был убит татарами. Под Вармией поляки и татары разбили войска брандербугско-прусского курфюрста. Эти успехи, а также Виленское перемирие и вступление в войну Дании вынудили шведов отступить, пруссов устраниться от войны с поляками, шведы перекинули войска против русских и начали выводить войска из Речи Посполитой. Эти обстоятельства осложнили положение Дьёрдя Ракоци, а вторжение Любомирского и австрийского войска в трансильванские земли стали неприятной неожиданностью. Венгры начали отступать, и под Магеровым и Куликовом поляки под руководством Чарнецкого победили их. Дьёрдь Ракоци отступал к Зборову, а потом к Черному Острову. Там на него напали Чарнецкий и Сапеги, и трансильванский князь был вынужден отречься от польского престола, войска же Ждановича отделились от венгров еще перед битвой [Величко].

Сообщалось, что татары с венграми мир не заключали, напали на них, и войско Дьёрдя Ракоци потеряло 5 тыс., а Януш Кемень попал в плен к крымцам. Войско Дьёрдя Ракоци II составляло 13 тыс. венгров и 6 тыс. молдаван и валахов. Г. Санин высказывался в пользу 20 тыс. венгров и 6 тыс. валахов и молдаван в его войске. Эвлия Челеби сообщал о 60 тыс. венгров, что, конечно, очень большое преувеличение. Общее количество татарских воинов он указывал в 80 тыс. чел. Говорилось, что к татарам из Гданьска поступило десять возов кошельков. Турецкий хронист отмечал бегство Дьёрдя Ракоци II и отмечал, что мужественный Я. Кемень оковал цепями табор и защищался. Крымцы оказали помощь Речи Посполитой не сразу, поскольку зимой 1656-1657 гг. произошел падеж скота, а также на владения ханства напали донцы. Крымский хан ответил осадой города Черкесска и лишь весной отправил. Вскоре трансильванский князь покинул войска, а войском управлял Я. Кемень [Санин, 2005, с. 100-125], [Эвлия Челеби].

П. Гордон сообщал, что венгров окружили крымцы в числе 60 тыс. На войско Я. Кеменя 
оказывалось мощное давление, но обороняющиеся вагенбургом венгры смело отражали татар при помощи мушкетов и пушек. Татары же массированно обстреливали противника из луков, нанося ему потери. Многие тягловые животные были перебиты, а продовольствие закончилось около Меджибожа. Наиболее храбро в войсках трансильванцев сражались молдаване, но когда татары переоделись в турков, то пришли в замешательство и восстали. После этого войско Я. Кеменя капитулировало, когда крымцы пообещали им дать дорогу домой. Однако крымцы, как только венгры разомкнули ряды возов, напали на них [Гордон].

Венгры сражались храбро, однако были разбиты, и 275 знатных человека попали в плен. Их выкупили за 123 тыс. золотых. В Трансильванию из этих пленных не вернулись 23 человека. Если же говорить о количестве всех пленных, то их было около 4 тыс. Я. Кеменя не утвердили как князя Трансильвании, поскольку он был пленником хана, а выкупом пленных занялся М. Апафи, который через некоторое время стал князем [Иванич, с. 126-134].

Политика Крымского ханства была направлена на поддержание равновесия сил в Восточной Европе. Отношения Крымского ханства с Украиной (Гетманщиной) были достаточно сложными. Заключение сепаратного мира с Речью Посполитой в конце 1653 г. привело к разрыву с украинцами, который, однако, не был окончательным. В кампании 1654-1655 гг. крымцы не допустили разгрома Б. Хмельницкого под Ахматовым, который смог договориться с Мухаммедом-Гиреем IV. Даже окружение украинцев ханским войском под Озерной не привело к разгрому украинцев, а хан и украинский гетман вели активные переговоры. Хан не упускал возможности договориться с Б. Хмельницким. В полную силу крымцы воевали против других врагов Речи Посполитой. В битве под Простками крымцы помогли полякам одолеть шведов, а рейд в Пруссию вынудил местного правителя прекратить активную войну против польского короля. Сражение с войсками Дьёрдя Ракоци II привело к полному разгрому венгров.

\section{Литература}

Иванич M. Трансильванские пленники в Крымском ханстве в 60-е годы XVII века // Государственность, дипломатия, культура в Центральной и Восточной Европе. М., 2005. С. 126-134.

Краткая история о бунтах Хмельницкого и войне с татарами, шведами и уграми в царствие Влади- слава и Казимира, в продолжение двенадцати лет, начиная с 1647 г. // Чтения в Императорском обществе истории и древностей российских при Московском университете. № 4. M., 1846. URL: http://litopys.org.ua/samovyd/sam12.htm (дата обращения: 20.01.2019).

Малов A. В. Русско-польская война 1654-1667. М.: Цейхгауз, 2006. 50 с.

Санин Г. А. Отношения России и Украины с Крымским ханством в середине XVII в. М.: Наука, $1987.270 \mathrm{c}$.

Санин Г. А. Россия, Украина, Трансильвания в системе международных отношений середины XVII в. // Государственность, дипломатия, культура в Центральной и Восточной Европе. М., 2005. С. 100125.

Черниговская летопись // Южнорусские летописи. Киев, 1856. URL: http://litopys.org.ua/bilozer/ bilz01.htm (дата обращения: 20.01.2019).

Эвлия Челеби. Книга путешествия (Извлечения из сочинения турецкого путешественника XVII века). Вып. 1. Земли Молдавии и Украины. М.: Восточная литература, Наука, 1961. URL: http://www.vostlit.info/Texts/rus8/Celebi3/text3.phtml?i $\mathrm{d}=1729$ (дата обращения: 20.01.2019).

Софонович $\Phi$. Хроніка з літописців стародавніх. К.: Наукова думка, 1992. 336 с.

Величко С. В. Літопис. Т. 1. К.: Дніпро, 1991. 371 c. URL: http://litopys.org.ua/velichko/vel.htm (дата обращения: 20.01.2019).

Гордон П. Дневник 1635-1659. Т. 1. М.: Наука, 2001. URL: http://www.vostlit.info/Texts/rus13/ Gordon/frametext3.htm (дата обращения: 20.01.2019).

Грушевський М. С. Історія України-Русі. Т. 9. Кн.2. К.: Наукова думка, 1997. 776 с. URL: http://litopys.org.ua/hrushrus/iur9.htm (дата обращения: 20.01.2019).

Лизогубівський літопис // Сборник летописей относящихся к истории Южной и Западной Руси. Киев, 1888. URL: http://litopys.org.ua/sborlet/ sborlet02.htm (дата обращения: 20.01.2019).

Літопис гадяцького полковника Григорія Грабянки. К.: Т-во Знання України, 1992. 192 с. URL: http://litopys.org.ua/grab/hrab.htm (дата обращения: 20.01.2019)

Літопис Самовидця. К.: Наукова думка, 1971. 208 c. URL: http://litopys.org.ua/samovyd/sam.htm (дата обращения: 20.01.2019).

Мицик Ю. А. Джерела 3 історії Гаціональновизвольної війни (1655-1658). Т. 4. К.: Інститут української археографії та джерелознавства ім. М. С. Грушевського, 2015. 540 с.

Мицикк Ю. А. Літописець Дворецьких - памятник украинского летописания XVII в. // Хроники и летописи 1984. М., 1984. URL: http://litopys.org.ua/ samovyd/sam15.htm (дата обращения: 20.01.2019).

Найма Мустафа. Гюсейнові городи у витягу історій із заходу та сходу. К.: Вид-во Жупанського, 2016. 288 c. 
Перналь А. Б. Річ Посполита двух народів і Україна. Дипломатичні відносини 1648-1659 рр. К.: ВД Київсько-Могилянська Академія, 2013. 400 с.

Смолій В., Степанков В. Українська національна революція XVII ст. (1648-1676). К.: ВД КиївськоМогилянська Академія, 2009. 447 с.

Федорук Я. О. Посольства Кримського хана Мегмеда Гірея до Швеції, Данії та Австрії у 1655 р. // Український історичний журнал. № 5. Київ, 2010. С. 37-50.

Федорук Я. Політика Кримського ханства в Охматівський кампанії 1654-1655 pp. // Чорноморська минувщина. Вип. 2. Одесса, 2012. С. 3-11.

Федорук Я. Українсько-польська війна в політиці Кримського ханства, Росії і Придунайських князівств (кінець 1654 - початок 1655 рр.). // Проблеми історії країн Центральної та Східної Свропи. Вип. 2. Київ, 2011. С. 83-100.

Чухліб T. Козаки і татари. Українсько-кримські союзи 1500-1700-х років. К.: ВД КиєвоМогилянська академія, 2017. 274 с.

Чухліб T. Козаки та яничари. Україна в християнсько-мусульманських війнах 1500-1700 pp. К.: ВД Київсько-Могилянська Академія, 2010. 446 с.

Шерер Ж. Б. Літопис Малоросії або країни козаків-запорожців та козаків України, або Малоросії. К.: Український письменник, 1994. 311 с. URL: http://litopys.org.ua/scherer/sher03.htm (дата обращения: 20.01.2019).

Erlicz. Latopisiec albo Kroniczka Joachima Jerlicza. T. 1. Warszawa: W drukarni Wienhoebera, 1853. URL: http://books.google.com.ua/books?id= tkghAQAAMAAJ\&printsec $=$ frontcover $\& \mathrm{hl}=\mathrm{uk} \&$ source $=$ gbs_ge_summary_r\&cad $=0 \# \mathrm{v}=$ onepage $\& \mathrm{q} \& \mathrm{f}=$ false (дата обращения: 20.01.2019).

Historya o buntach Chmielnickiego, o wojnie z Tatarami, ze Szwedami i z Węgrami za króla Władysława IV i za Jana Kazimierza przez lat dwanaście, krótko zebrana, ab anno 1647, anno 1648.
URL: $\quad$ http://pbc.gda.pl/dlibra/doccontent?id=6295\& from=FBC (дата обращения: 20.01.2019).

Kochowski Wespazjan. Historya panowania Jana Kazimerza. T. 1. Poznan: Nakladem i Czcinkami N. Kamienskogo i spolki, 1859. URL: http://dir.icm.edu.pl/pl/Historya_panowania_Jana_Kazi mierza/Tom_1/ (дата обращения: 20.01.2019).

Miron Costin. Letopisețul Țărîi Moldovei de la Aaron Vodă încoace. URL: https://ro.wikisource.org/wiki/ Letopise\%C8\%9Bul_\%C8\%9A\%C4\%83r\%C3\%AEi_ Moldovei_de_la_Aaron_Vod\%C4\%83_\%C3\%AEncoac е (дата обращения: 20.01.2019).

Podhorodecki L. Chanat Krymski i jego stosunki s Polska. Warszawa: Książka i wiedza, 1987. 359 s.

Twardowski S. Wojna domowa z Kozaki, Tatary, Moskwa, potym szwedami i z Wegry przez lat dwanascie za panowania Nayjasnieyszego Jana Kazimierza Krola Polskiego. Calissii: Typ. Collegii Callissiensis, 1681. URL: http://books.google.com.ua/ books?id=yk0_AAAAcAAJ\&printsec $=$ frontcover $\& \mathrm{hl}=\mathrm{u}$ $\mathrm{k} \&$ source $=\mathrm{gbs} \_\mathrm{ge} \_$summary_r $\&$ cad $=0 \# \mathrm{v}=$ onepage $\& \mathrm{q} \&$ $\mathrm{f}=$ false (дата обращения: 20.01.2019).

Kolodzejczyk D. The Crimean khanate and PolandLithuania: international diplomacy on the European periphery $\left(15^{\text {th }}-18^{\text {th }}\right.$ century): a study of peace treaties followed by annotated documents. Leiden-Boston: E. J. Brill, 2011. XXXVI, 1109 p.

Gaspard de Tende - Das Bey noch zweiffelhaffter Wahl eines neuen Königs ganz Verwirrte und Unruhige Polen: Worinnen Zugleich von dieser Republique Stärcke und Schwäche, Vortheile und Mängel absonderlich von der Eingeschränckten Gewalt Ihrer Könige ... umbständlich gehandelt wird: Vorhero in Französischer Sprache beschrieben, anjetzo ... in das Hochteutsche übersetzet. 1697. Coln: Pierre Matheau, 1697. 172 s. URL: http://books.google.com.ua/ books?id=6D9NAAAAcAAJ \& printsec $=$ frontcover $\&$ hl $=$ uk\&source=gbs_ge_summary_r\&cad $=0 \# v=$ onepage $\& \mathrm{q}$ $\& f=$ false $\quad$ (дата обращения: 20.01.2019).

\title{
1654-1657 ЕЛЛАРДА РЕЧЬ ПОСПОЛИТАЯ һӘМ КЫРЫМ ХАНЛЫГЫ АРАСЫНДАГЫ БЕРЛӘШМӘНЕН ХӘРБИ АСПЕКТЫ
}

\author{
Ярослав Валентинович Пилипчук, \\ М. П. Драгоманов исемендәге Милли педагогия университеты, \\ Украина, 03037, Киев ш., Освита (Мәгърифәт) ур., 6 нчы йорт, 24 каб., \\ bachman@meta.ua.
}

\begin{abstract}
Әлеге мәкаләдә Кырым ханлыгының Речь Посполитая белән 1654-1657 еллардагы берләшмәсенең хәрби һәм дипломатик аспектлары турындагы мәсьәлә тикшерелә. 1654 елда Көнчыгыш Европадагы халыкара мөнәсәбәтләр системасын үзгәртеп кору барлыкка килә. Гетманщинаның Рус дәүләте протекторатына күчүе Гәрәйләр һәм Ваза династияләре арасындагы тыгыз хезмәттәшлеккә сәбәп була. Кырым татарларының поляклар ягына чыгуы Запорожье казакларын оборонага күчәргә мәжбүр итә. 1655 елда Ахматов янындагы сугышларда Б. Хмельницкийның дипломатик сәләте, И. Богунның уңышлы һөжүме һәм Мәхмәд-Гәрәй IV белән кырым морзалары тарафыннан берәр якның ахыргача жиңүен булдырмаска омтылышы рус-украин гаскәрләренә жиңелмәскә мөмкинлек бирә. 1655 елда
\end{abstract}


Озерная янында булган сугышта украиннар шактый зур югалтуларга дучар була. Кырым татарларының Простки һәм Чорний Острив янындагы сугышларда полякларга ярдәме брандербурглылар һәм трансильваниялеләрнең жиңелүенә китерә. Поляк элемтәләре аша кырымлылар Австрия империясе, Дания һәм Швециягә илчелекләр жибәрә. Русларга каршы коалициягә Дания һәм Швецияне жәлеп итәргә омтылу уңышсыз булып чыга. Кырымлыларның 1657 елда трансильваниялеләргә каршы кампаниясе Госманлылар тарафыннан санкцияләнә.

Төп төшенчәләр: Речь Посполитая, Гетманщина, кырым татарлары, Кырым ханлыгы, халыкара мөнәсәбәтләр, Гәрәйләр.. 